Discussion Paper No. 15-018

Good Enough!

Are Socially Responsible Companies

the More Successful

Environmental Innovators?

Christiane Reif and Sascha Rexhäuser

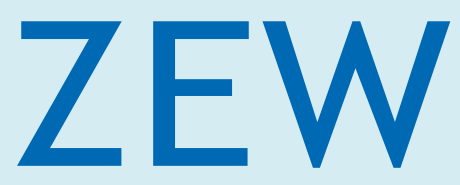

Zentrum für Europäische Wirtschaftsforschung $\mathrm{GmbH}$

Centre for European

Economic Research 
Discussion Paper No. 15-018

\title{
Good Enough! Are Socially Responsible Companies the More Successful Environmental Innovators?
}

\author{
Christiane Reif and Sascha Rexhäuser
}

Download this ZEW Discussion Paper from our ftp server:

http://ftp.zew.de/pub/zew-docs/dp/dp15018.pdf

Die Discussion Papers dienen einer möglichst schnellen Verbreitung von neueren Forschungsarbeiten des ZEW. Die Beiträge liegen in alleiniger Verantwortung der Autoren und stellen nicht notwendigerweise die Meinung des ZEW dar.

Discussion Papers are intended to make results of ZEW research promptly available to other economists in order to encourage discussion and suggestions for revisions. The authors are solely responsible for the contents which do not necessarily represent the opinion of the ZEW. 


\title{
Good enough! Are Socially Responsible Companies the more Successful Environmental Innovators?
}

Christiane Reif ${ }^{a}$ and Sascha Rexhäuser ${ }^{b}$

\begin{abstract}
:
The link between Corporate Social Responsibility (CSR) activities and financial performance of firms has been intensively examined and debated in academics and politics, but the connection to innovation has so far lacked research attention. This paper investigates whether CSR is complementary to environmental innovations, so that a joint introduction of both strategies generates a higher financial performance than the application of one or none of the strategies. We analyse if environmental innovators can generate higher financial performance by signalling their environmental engagement through CSR. For this purpose, we use panel data of environmental R\&D activity together with a CSR variable on the Global Reporting Initiative (GRI) and analyse their effect on the financial performance of a firm. The novelty of our work is the complementary approach with which we examine the effect of a joint strategy of environmental R\&D and CSR on financial performance. Although our results support the view of strategic complements for environmental R\&D and GRI, we cannot conclude that this is also true for other types of CSR signalling environmental engagement.
\end{abstract}

Keywords: $\quad$ complementarity, environmental R\&D, CSR, signalling, reputation, Global Reporting Initiative

JEL-Classification: O32, Q56

Acknowledgements: This work is out of the Project Impact Measurement and Performance Analysis of CSR (Corporate Social Responsibility), funded by the EU (7th Framework Program), Brussels, BE. We are indebted to the participants of seminars and workshops held in Évora, Frankfurt (Oder), Mannheim, and Toulouse for their comments.

\footnotetext{
${ }^{\mathrm{a}}$ Correspondence: Christiane Reif, Centre for European Economic Research (ZEW), L7,1, D-68161 Mannheim, Germany, email: reif@zew.de.

b Sascha Rexhäuser, Centre for European Economic Research (ZEW), L7,1, D-68161 Mannheim, Germany and Katholieke Universiteit Leuven (KU Leuven), Naamsestraat 69, B-3000 Leuven, Belgium, email: rexhaeuser@zew.de.
} 


\section{Introduction}

In the last years, an increasing environmental awareness in the societies of especially industrialized countries can be recognized. The consumers' willingness to pay (WTP) a price mark-up for 'green' products provides the opportunity for firms to gain profits and separate from competitors by offering such products (Russo and Fouts 1997) or by revealing their over-compliance on unobservable attributes through voluntary programs with publicly available information. Empirical evidence provide e.g. Arora and Cason (1995) and for theoretical background on vertical differentiation see Arora and Gangopadhyay (1995). Bénabou and Tirole (2010) classify this phenomenon as delegated philanthropy of stakeholders. The industry makes use of this trend by supplying products including environmental and sustainable aspects in the production process or with products shaped to fit the changed customers' expectations. These often called 'green' products can be subsumed as impure public goods in economic literature (see e.g. Kotchen 2006). Furthermore, on the capital market 'green' investors might also be attracted by firms providing such goods or producing in a socially and environmentally friendly way (see Graff Zivin and Small 2005 as one of the few theoretical concepts in this context). ${ }^{3}$

It is noticeable that in recent years more and more companies appear to be socially and environmentally responsible on a voluntary basis (Poddi and Vergalli 2009). These voluntary actions of firms are called Corporate Social Responsibility (CSR). The reasons for such a selfregulation can be divided into three main categories (see Lyon and Maxwell 2008). ${ }^{4}$ The first one is cost saving considerations. This is especially true in the environmental context where e.g. the reduction of used resources or energy efficiency measures lead to less environmental impact of production and at the same time can decrease costs (see Porter and van der Linde 1995). Second, voluntary action could be applied to avoid future threats of regulation (see Maxwell, Lyon, and Hackett 2000 for a theoretical approach) or attacks by activists (for theoretical models see Baron 2009, Baron and Diermeier 2007, Calveras and Ganuza 2007, Feddersen and Gilligan 2001). And third, voluntary social or environmental action could be driven by the demand side of 'green' consumers or 'green' investors, on which we base the considerations of our paper.

In this paper we concentrate on voluntary actions of firms in the environmental context. The communication of the firm's environmental performance can help the firm in its competition for socially responsible clients (Kitzmueller and Shimshack 2012). The firm knows about its environmentally friendly activities, but for its consumers, workers and investors, this information is not easy to get, to aggregate or to compare (Bénabou and Tirole 2010). While products can carry information about their environmental performance, this information is not directly observable for processes. Akerlof (1970) originally addressed the problem of information asymmetry arising from either adverse selection - when managers do not share

\footnotetext{
${ }^{3}$ There is a rich body of empirical evidence on the impact of regulation-triggered compliance activities on firm performance. Although previous research on this issue has been initiated starting in the early 1980s after the US and other industrialized nations introduce stricter environmental regulations, there is, however, no clear-cut picture of this relationship even until today. The rather early research is reviewed by Jaffe, Peterson, Portney, and Stavins (1995) whereas a more recent survey is offered by Ambec et al. (2013).

${ }^{4}$ Please see Lyon and Maxwell (2008) for a detailed discussion of the theoretical approaches and the welfare aspects of CSR.
} 
information - or from unobservable attributes (moral hazard) and provided examples like certification to overcome information asymmetry. We argue that CSR can carry unobservable organizational qualities to reduce information asymmetry. This is based on the signalling model explained by Spence (1973) for the job market context and applied to the financial market by e.g. Ross (1977) or Bhattacharya (1979), in which signals serve as information on unobservable attributes (see Spence 2002). ${ }^{5}$ The critical requirement for such signals is that the costs are high enough to prevent low performing firms from defection and low enough that the high performing firms can profit from disclosure (see e.g. Milgrom and Roberts 1986, Watts and Zimmermann 2002, pp 164-165). Nevertheless, Wernerfelt (1988) shows for brands signalling new product's quality that these restrictive assumptions might be defined down. The main theoretical assumption behind is that signalling becomes cheaper for those firms with high reputation, e.g. branding, as these firms can built up on previous reputation and signal not only for a single product, but for a bunch of products. On the other side, sending false signals is more costly from the signalling period onwards than sending no signal at all. We apply the idea of reputational economies of scales by Wernerfelt (1988) to our approach while CSR not signalling the specific attributes of one product, but the firm's environmental R\&D activity as a whole. CSR certification - such as the Global Report Initiative (GRI) - are regarded as credible signal to transport firms' attributes which cannot be observed easily and creates reputation (see e.g. Toms 2002). Like in Terlaak and King (2006), we assume that CSR signals these desired qualifications of firms, in our case information about the environmental attributes of a firm. As such, CSR enhances the reputation on environmental activities of the firm which is rewarded at the market by consumers, investors or business partners.

The research question is, whether a joint strategy of environmental innovation and CSR engagement leads to a higher financial performance than a decision for either one or none of these strategies. In this paper we analyse if firms can generate higher financial performance by jointly implementing both strategies compared to specialising in the environmental context. We focus on environmental $R \& D$ and CSR, which could signal environmental attributes of firms. In specific, we use Thompson and Reuters ASSET4 (A4) database of large global companies in panel-structure to analyse the long-term effects of a joint implementation of environmental R\&D and CSR action on the firm's market value accounted for by the priceto-sales ratio. The underlying assumption is that CSR signals the environmental performance of a firm, in our approach the environmental $R \& D$ engagement, which indicates not only the current firm's activity, but also the long-term engagement into environmental responsibility.

The results support the view that both strategies (to be active in environmental innovation and certified CSR) act as strategic complements in terms of companies’ market value. Introducing a single strategy alone does not significantly affect financial performance while companies that adopted both strategies jointly are observed to have a significantly higher market value scaled by total sales compared to the control group. In this sense, the results support the view that a credible signal is needed to successfully disclose otherwise private information on companies' environmental performance. The disclosure of information on environmental

\footnotetext{
${ }^{5}$ Please see Riley (2001) for an overview and discussion on the literature of signalling.
} 
performance can be seen as a signal for the amount of companies' $R \& D$ expenditures allocated to environmental innovation strategies that are otherwise rather hard to observe.

The remainder of the paper is organised as follows. Section 2 reviews related research and discusses how the current paper contributes to the ongoing debate. Section 3 provides theoretical thoughts on the underlying mechanism based on theories of the firm. This section serves as a theoretical guidance for the choice of variables described in Section 4 and the empirical analyses described and set up in Section 5 followed by the presentation and discussion of the results in section 6 and further robustness checks in section 7 . Section 8 concludes and Section 9 provides managerial implications.

\section{Related literature}

The term Corporate Social Responsibility (CSR) is not commonly defined. In literature and practice several definitions exist, but two common aspects of CSR can be found in these definitions: CSR activities relate to social and environmental issues and go beyond legal requirements. For our analyses we use a CSR variable (explained later in detail) based on this definition which covers profit-maximising, profit-neutral and profit-sacrificing CSR actions. ${ }^{6}$ The development of the topic CSR in the research agenda can be visualised with published journal articles (see Figure 1 Appendix). The number of CSR articles has increased especially in the last 10 years with a shift in the years 2007 to 2011. The percentage, however, of the total amount of publications in Management and Economy is rather small. Concerning the topic innovation, the publications have increased from the 1970s onwards with a huge shift in the years 2007 to 2011 and with a large share of overall publications in Management and Economy. In the empirical research on CSR, an overwhelming number of studies address the connection of CSR and financial performance (FP), mostly focusing on how CSR influences financial performance. Cochran and Wood (1984), Pava and Krausz (1996), as well as Griffin and Mahon (1997) provide literature reviews of early research in their studies. The metaanalyses by Orlitzky et al. (2003) or Margolis et al. (2007) give an impression on the huge number of empirical studies on the CSR-FP relationship. Their overall results indicate a positive correlation of CSR and FP. As such, Orlitzky et al. (2003) find a bi-directional relationship and a slightly positive effect of CSR on FP (Margolis et al. 2007).

However, empirical analyses taking innovation as a factor in the empirical estimations into account are rare. Hart and Ahuja (1996) include innovation in form of R\&D per sales as a control variable for their analyses of how CSR affects different types of operational and financial performances of a firm. They observe a positive effect of preventing pollution on financial performance with a one or two year time-lag. The empirical research by McWilliams

\footnotetext{
${ }^{6}$ Besides this broad sense of definition also narrower interpretations of CSR can be found in which CSR goes along with profit losses. Starting with the article by Friedman (1970) to the more recently published paper by Reinhardt et al. (2008) who clearly understand CSR as sacrificing profits by referring to Elhauge (2005). This profit-sacrificing type of CSR is also called altruistic CSR (see e.g. Baron 2001, Baron 2010, takes the altruistic explanation in a broader sense with the term reciprocal altruism, which is conditional on partners action and benefits). This viewpoint with firm's profits and pro-social or environmental behaviour as trade-offs is for example criticised by Bowen (2007). Carroll (2013) takes the different viewpoints on social responsibility together as four responsibilities of a firm, namely economic, legal ethical and discretionary responsibilities. The two last once include voluntary action by the firm, but leave open how they would affect the financial performance of a firm.
} 
and Siegel (2000) is based on two main arguments: innovation has a positive effect on FP, and CSR and innovation are strongly correlated. They prove that ignoring innovation might lead to an over-estimation of the CSR effect on financial performance, as they find a neutral effect of CSR on FP as soon as innovation is included as explanatory variable. Hull and Rothenberg (2008) extend the study by McWilliams and Siegel (2000) with an additional model in which CSR and innovation are not only included as single variables, but also as interaction terms. They base their approach on the assumption that firms can differentiate via innovation or CSR. They conclude that CSR positively influences FP, furthermore that innovation is an important explanatory variable in this context, and that innovation and CSR are substitutes in terms of firm differentiation. Another study based on McWilliams and Siegel (2000) is conducted by Lioui and Sharma (2012) who examine how environmental CSR affects returnon-assets (ROA) and Tobin's Q directly and indirectly via R\&D. They construct a possible additional return on R\&D investments of CSR firms with an interaction term of CSR and innovation. They explain the negative direct effect of CSR on FP with the costs of CSR measures and attribute the positive indirect effect to more efficient R\&D (Lioui and Sharma 2012). In contrast to these studies, we investigate whether a CSR measure signalling proenvironmental action of the firm is complementary to environmental innovations - so that a joint introduction of both generates higher financial performance - or if a substitutive character can be verified. Cavaco and Crifo (2014) also use a complementarity approach, but in their case they employ it to analyse three dimensions of CSR, namely responsible behaviour towards employees, customers and suppliers, and the environment. They find that firms caring about employees and at the same time about customers and suppliers can gain profits. Furthermore, firms should decide on either environmentally friendly behaviour or responsible behaviour towards customers and suppliers and not engage in both of them at the same time.

Beside these studies which mostly use scores as an overall indicator for firm's social and environmental activities, research with a focus on environmental performance is of interest for our analysis. This literature is strongly related to the Porter hypothesis, stating that environmental regulation implies innovation and in turn generates a competitive advantage for a firm (see Porter and van der Linde 1995). Rexhäuser and Rammer (2014) test the Porter hypothesis for German companies and find that it does not hold in general and depends on the type of environmental innovation. A study closely related to the CSR context by Klassen and McLaughlin (1996) empirically examines the effect of environmental awards on financial performance. In their event study on the firm level, they find significantly positive effects. Another study by Konar and Cohen (2001) shows that negative environmental performance effects financial performance negatively. They measure the environmental performance as emitted toxic chemicals and as lawsuits against the firm. Russo and Fouts (1997) use environmental ratings as environmental performance indicators and observe a positive impact on financial performance. Research approaches using panel data have arisen in the last years, to respond to the criticism of not considering unobserved firm heterogeneity in cross-sectional studies. Among them is a study on US firms by King and Lenox (2001) showing that firms' attributes may drive the effect on financial performance. Elsayed and Paton (2005) find in a dynamic panel data analysis for UK firms that there is a neutral effect of environmental performance on financial performance. Telle (2006) confirms this result for Norwegian firms. 
Connected to the research on environmental performance and its effect on a firm's performance are empirical studies on environmental management systems (EMS). Studies on the determinants of environmental management systems reveal that consumer preferences have a strong impact on firms' engagement in EMS certification (Nakamura et al. 2001, Potoski and Prakash 2005, Nishitani 2009, Nishitani 2010). In contrast, Harrington et al. (2008) find that firms' internal factors are the driving forces to implement environmental management. Further empirical research focuses on the effects of EMS on either the environmental performance to evaluate the usage of EMS as a policy instrument (see e.g. Dasgupta et al. 2000, King and Lenox 2000) or on innovation (see e.g. Wagner 2007 for German firms). Concerning the effect of EMS on firm performance, Melnyk et al. (2003) examine the relative effects of uncertified and certified EMS based on a survey among North American managers and find that EMS have a positive effect on environmental as well as firms’ performance. Rennings et al. (2006) examine both the effect of EMS on technical innovations as well as on financial performance. They find that the learning process of EMS has a positive effect on product innovation, which in turn positively influences economic performance. An event study by Cañón-de-Francia and Garcés-Ayerbe (2009) shows that proactive EMS engagement leads to positive and reactive EMS to negative market returns.

More related to the signalling concept is research especially applied to the ISO 9000 and the ISO 14000 standard as certified standards (see Heras-Saizarbitoria and Boiral 2013 for a literature overview). ${ }^{7}$ Heras-Saizarbitoria and Boiral (2013) categorize signalling models as non-technical, theoretical approaches. Terlaak and King (2006) apply certified standards to the signalling model and find that the ISO 9000 certification leads to a competitive advantage especially in large and advertising-intensive industries with high information costs. However, there are studies finding no support that ISO 14000 certification has a positive effect on financial performance (e.g. Heras-Saizarbitoria et al. 2011 for Spanish firms) or even has a negative effect on the market value if the firms are less polluting and less internationalised (Cañón-de-Francia and Garcés-Ayerbe 2009). Nevertheless, Toms (2002) shows for UK firms that the disclosure of firm's environmental activities in annual reports creates reputation. The reputation may in turn lead to a competitive advantage.

Based on these empirical studies, our approach, which analyses if CSR, signalling environmental engagement, is complementary to environmental innovation and effects financial performance positively, seems plausible. Contrary to the neoclassical assumption that CSR engagement always means sacrificing profits (Friedman 1970), we rather rely on a win-win assumption of CSR and financial performance. This is in line with the conclusion by Orlitzky (2005) that CSR and financial performance are no trade-offs and also supports the legal aspect that it is not easy for a manager to sacrifice profits in the social interest (Reinhardt et al. 2008). Nevertheless, our approach aims to shed light on the connection of CSR and innovation and their effect on financial performance - complementary or substitutive.

\footnotetext{
${ }^{7}$ In contrast, the ISO 26000 is only a guideline for companies how they should behave, but do not include any requirements. Therefore, ISO 26000 is not certifiable like ISO 14000 and ISO 9000.
} 


\section{Theory of the firm and hypothesis}

\section{Firm theory and CSR strategy}

Husted and Allen (2000, 2007a, 2007b) explain the strategic allocation of resources to fulfil social objectives in the long-run and at the same time to gain profits as a 'corporate social strategy'. But how is this corporate social strategy connected to the overall firm strategy? Especially when researchers like Margolis et al. (2007) state that most studies only analyse the unilateral relationship between CSR and financial performance, but the mechanisms and the direction of causality are unclear. Although, most literature explaining the relation of CSR and financial performance are either related to the slack resources approach or the stakeholder approach, the overall firm strategy is often neglected. The neoclassical firm theory with rational actors aiming at maximising profits might fall short to explain CSR activities. The behavioural and the resource-based theory of the firm provide explanations of firms' CSR engagement (Bowen 2007, Branco and Rodrigues 2006), which we focus on in our analyses of the relationship between innovation, CSR and financial performance. ${ }^{8}$

The behavioural theory is traced back to Cyert and March (1963) with the assumption of mangers' bounded rationality as the main difference to neoclassical firm theory. Furthermore, firms are seen as coalitions of individuals with personal values. Therefore, several endogenously arising organisational goals with possibly contradicting character exist. Applying the behavioural theory to a CSR strategy reveals the importance of slack resources in this context. As such the slack resources (see e.g. Waddock and Graves 1997, Orlitzky et al. 2003) as well as the so-called available funding theory (Preston and O’Bannon 1997) imply that prior FP is associated with subsequent CSR. One example for such a CSR activity is the action of donating. At least the decision on the amount of the donation depends on the financial resources of the company. This would imply that firms with a better financial performance than their counterparts have more freely available resources, which can be used for CSR activities. Examples for empirical analyses on the slack resources theory are McGuire, Sundgren, and Schneeweis (1988) and Waddock and Graves (1997). Nevertheless, Bowen (2007) emphasises the necessity of slack resources but, as behavioural theory suppose personal values as the origin of a social strategy, slack resources (as e.g. strong finances) alone do not lead to CSR engagement.

The resource-based view ( $R B V$ ) of the firm, which goes back to Penrose (1959), takes the perspective that a firm is a bundle of resources (Wernerfelt 1984) with the two main assumptions of resource heterogeneity and resource immobility (see Bowen 2007). Therefore, the RBV takes the standpoint that competitive advantage is created within the firm depending on the characteristics and usage of its resources. Especially unique resources and their clever deployment contribute to the firm's success. Thus, these specific firm capabilities can generate competitive advantage in the long-run. According to Branco and Rodrigues (2006), reputation is an intangible resource which could be affected by firm's CSR activity.

\footnotetext{
${ }^{8}$ See also Bowen (2007) for distinction to the neoclassical theory of firms and a discussion on applicability to firms' behaviour of the different theories.
} 
Although the RBV focuses on the firm's internal characteristics, the external environment determines the organisational goals by threats from stakeholders (see e.g. Wernerfelt 1984). ${ }^{9}$ In general, the stakeholder concept means the inclusion of interests not only of shareholders per se, but also of outside stakeholders. Freeman (2010, p 25) describes stakeholders as "[...] any group or individual who can affect or is affected by the achievement of the firm's objectives." Donaldson and Preston (1995, figure 2) specify groups like governments, investors, political groups, suppliers, trade associations, employees, communities and customers. According to Freeman (2010), the difference of the stakeholder approach to CSR lies in the extension to additional stakeholders. CSR is a source of capabilities driven by stakeholders when applying the corporate social strategy to RBV. ${ }^{10}$ As such CSR creates reputation and in turn increases financial performance (see e.g. McGuire et al. 1988, Waddock and Graves 1997), which is described as lead-lag relationship by Preston and O'Bannon (1997). In the environmental context, empirical examples for the application of RBV on CSR are researched by Hart (1995) or Russo and Fouts (1997).

\section{Hypothesis based on firm strategy}

In this paper, we analyse the effect of environmental innovation and CSR on FP. In this sense, we expect that CSR increases the marginal financial returns by introducing environmental innovation compared to a control group. This is because firms with environmental innovations and certified CSR are expected to have a better financial performance, as they can differentiate themselves from their competitors by verifying their environmentally friendly behaviour through CSR and verify their ongoing engagement in the future through todays' R\&D spending and thus convince stakeholders such as consumers, investors, and trading partners with this reputation. We test the hypothesis whether firms that jointly innovate and engage in CSR have better financial performance values. We assume that this is in congruence with the signalling hypothesis and the RBV theory of the firm, as especially the returns to (or outcome of) R\&D investments are hard to observe (see e.g. Aboody and Lev 2000, Chauvin and Hirschey 1994) and can be seen as intangible assets. The same may hold true in particular for the case of environmental R\&D efforts and its outcome. We assume that CSR serves as a signal to overcome this information asymmetry by at least partial disclosure of a firm's environmental activities, especially related to environmental $R \& D$ and thus a longterm engagement into environmental responsibility. This in turn helps to create a firm's positive reputation and trustworthiness and might also support the company in vertical differentiation from their competitors (see. e.g. Fombrun 1996, Fombrun and Shanley 1990). Therefore, we formulate the following hypothesis for our analysis on complementarity of environmental R\&D and CSR.

Hypothesis: Firms jointly engaged in environmental innovations as well as CSR can gain ceteris paribus better financial performance (market values scaled by total sales).

As such, we analyse the joint implementation of environmental innovation and CSR and compare their effect on financial performance to firms that neither introduced environmental

\footnotetext{
${ }^{9}$ The internal and external environment of the firm and how to relate these aspects is also object of the contingency theory. Smith and Lewis (2011) relate the stakeholder perspective to contingency theory as performing paradoxes, where multiple stakeholders demand different actions.

${ }^{10}$ See Bowen (2007) for implications of RBV for CSR.
} 
innovations nor CSR or only introduced one of those strategies independently of the other. Therefore, the causal direction is based on the RBV of the firm, even though our analysis allows also for neutral, negative or positive effects on financial performance. Furthermore, by discussing the signalling effect of CSR on clients beforehand, we contribute to the stakeholder theory with our research.

Our complementary approach tests if the joint introduction of innovation and CSR generates higher financial performance. The complementary approach enables us to differentiate between four exclusive types of engagement: companies just doing environmental innovation alone, companies exclusively engaged in CSR, companies jointly engaged in innovation and CSR, and companies neither innovating nor being active in CSR. This allows us not only to analyse if environmental innovation and CSR are complementary, but also the contrary substitutive relation. For our analysis we focus on environmental concerns of innovations and CSR.

\section{Database and Descriptive Statistics}

We base our research on worldwide company panel data from the Thompson and Reuters ASSET4 (A4) database, which allows us to get better insight into the process organisation of a company than by only using CSR score data (like in the CSR context often used Kinder, Lydenberg, Domini (KLD) database). Mainly large companies based in the US are included in the A4 database. The unbalanced panel A4 contains a collection of environmental, social, governance and financial data of more than 3,000 global companies listed in major indices such as S\&P 500, MSCI Europe, FTSE 350 and the MSCI World Index, Stoxx 300, Nasdaq, ASX 200. Publicly available information of a company (e.g. reports, but also other publicly available sources) is gathered yearly (beginning in 2002) by specially trained analysts with an increasing number of screened companies. Besides various factors of firm performance (such as stock market value, return on assets, among others) and the information on various CSR characteristics, the dataset provides a rather limited amount of information on central firmspecific factors likely affecting firms’ stock market value (e.g. patent stock).

Nevertheless, the panel data structure allows us to provide formal tests on whether CSR complements firms' environmental innovations in terms of financial performance or has a substitutive character. The restricted sample for our estimations consists of 6,737 observations including 1,945 firms. The sample extends over the years 2005 to 2009 as an unbalanced panel to ensure the availability of a two years' time lag for each variable (see Figure 2 Appendix). ${ }^{11}$

The variables of interest for our research on whether CSR complements environmental innovating companies are represented by 1,039 observations of environmental innovators (Figure 3) and 1,501 observations on CSR engagement (Figure 4) over the years 2005-2009. As the number of observations varies in the unbalanced panel, also the number of firms that reported environmental R\&D and CSR varies over the periods. The share of green innovators is over $5 \%$ in each year and the share of CSR active firms is higher than $8 \%$ in each year.

11 The drop in 2009 is due to the unbalanced panel structure and the availability of data needed for the estimations explainable. The raw data shows an increase of screened companies over the years. 
Figure 5 shows the number of observations of the years for the four exclusive types of engagement. In the observed years 2005-2009, most companies are not engaged in either one of the strategies. However, in all the years there are observations for all four categories.

As in the database, the observations of the restricted sample are comprised of mainly the following countries: United States (33\%), Japan (18\%), and United Kingdom (14\%). The European countries are represented with about 39\% of the observations. Concerning the four exclusive categories by continents, Figure 6 provides an overview that the most observations are from Europe, US, and Asia. Especially in Europe and Asia there are more observations of firms engaged in both strategies than on the other continents.

Furthermore, the 12 industry sectors are covered according to the Standard Industrial Classification (SIC) (Table 7). The finance, insurance and real estate sector is highly represented in our sample (19\%), followed by the Transport sector (13\%). Nevertheless, the various manufacturing industries result in almost the half of the observations in the sample (43\%) when taken together. With respect to the exclusive categories, Figure 7 displays that most observations are from the finance, insurance and real estate sector with only a few observations showing innovation or innovation and CSR engagement jointly. As product and process innovations are especially relevant for non-service sector, we find innovating firms or firms engaged in both strategies particularly in the manufacturing sectors.

The descriptive analysis of environmental R\&D and CSR indicates a correlation between both strategies. In the sample, the joint realisation of environmental innovation and CSR occurs with a higher frequency than the implementation of environmental innovation alone (Table 1).

Table 1: Adoption Decision and Relative Frequencies

\begin{tabular}{|c|c|c|c|c|c|c|c|}
\hline \multirow[b]{2}{*}{ EnvInno } & \multicolumn{2}{|c|}{ CSR } & \multirow[b]{2}{*}{ Total } & \multirow[b]{2}{*}{ EnvInno } & \multicolumn{2}{|c|}{$C S R$} & \multirow[b]{2}{*}{ Total } \\
\hline & 0 & 1 & & & 0 & 1 & \\
\hline 0 & $\begin{array}{c}4,754 \\
(4,429)\end{array}$ & $\begin{array}{c}944 \\
(1,270)\end{array}$ & 5,698 & 0 & $\begin{array}{c}83.43 \% \\
(77.73 \%)\end{array}$ & $\begin{array}{c}16.57 \% \\
(22.29 \%)\end{array}$ & $84.58 \%$ \\
\hline 1 & $\begin{array}{c}482 \\
(808)\end{array}$ & $\begin{array}{c}557 \\
(232)\end{array}$ & 1,039 & 1 & $\begin{array}{c}46.39 \% \\
(77.67 \%)\end{array}$ & $\begin{array}{c}53.61 \% \\
(22.33 \%) \\
\end{array}$ & $15.42 \%$ \\
\hline Total & 5,236 & 1,501 & 6,737 & Total & $77.72 \%$ & $22.28 \%$ & $100.00 \%$ \\
\hline $\begin{array}{l}\text { Expected } \\
\text { Pearson } \\
\text { Kendall's }\end{array}$ & $\begin{array}{l}\text { uencies } \\
1)=696.3 \\
-b=0.32\end{array}$ & $\begin{array}{l}\text { ar in par } \\
P r=0.0 \\
P>Z=0.0\end{array}$ & eses. & & & & \\
\hline
\end{tabular}

Table 1 also shows the frequency under the assumption of independency of both firm strategies in parentheses. Interestingly, if both strategy variables were independent, we would expect that only 232 firms had introduced both strategies jointly. However, the firms that actually implemented both are more than twice the number we would expect in case of independency. Together with the very high coefficient of association (Kendall's tau-b), Table 1 offers strong evidence for high correlation between environmental innovation and CSR of a firm. This is in line with considerations by Terlaak (2007) that firms in R\&D intensive industries can gain competitive advantage with certified standards. Nevertheless, the correlation of course is not sufficient for complementarity to be present. Whether this 
correlation survives multivariate statistics controlling for any other influencing factors and whether it really stems from complementarity is subject to the following empirical analysis.

Although the key variables of interest (i.e. whether CSR and environmental R\&D are implemented) are binary indicators, they vary considerably over time within the firms (see Table 8 in the appendix). 33.26\% of the 1,945 firms in our sample had CSR implemented in at least one year, whereas environmental $R \& D$ has been reported at least once for $24.27 \%$ of the firms. Approximately $9.51 \%$ of the firms reported CSR in place in all observed years. The respective number for environmental $\mathrm{R} \& \mathrm{D}$ is much lower, namely $6.84 \%$. More interestingly, 22.51\% of all firms introduced CSR at a certain year and continued doing CSR in all following years, which is approximately $67.70 \%$ of all firms observed to have CSR introduced in at least one year. In total, $24.27 \%$ of all firms are observed to have reported environmental R\&D at least once within the period 2005-2009. 15.42\% of all firms did environmental $\mathrm{R} \& \mathrm{D}$ in a certain year and continued doing so in all the following years. This is $63.56 \%$ of all the firms that are observed as having done environmental R\&D at least in one year. $2 \%$ of all 1,945 firms change their engagement over time with respect to $R \& D$ and $1.23 \%$ with respect to CSR activities.

\section{Estimation Strategy}

\subsection{Complementary Approach Basic Model}

Complementarity (in the sense of Edgeworth) in firm strategies means that doing more of one activity increases the marginal returns of doing more of the other. Which means that, certified CSR may signal environmental responsibility and thus increase the returns to environmental R\&D by making customers and stakeholders aware of this. In principle, there are two ways to estimate such a relationship: the adoption approach and the productivity approach, which is central to the present paper. Roughly put, the adoption approach relies on the correlation of two firm strategies in order to account for complementarity. Note that this approach is only valid in case of continuous strategy measures (Miravete and Pernías 2010) and thus not applicable in this paper. ${ }^{12}$

The productivity approach is not restricted to continuous variables and accounts for the performance effects of the potential complementary variables with respect to an objective function - in our case price-per-sales $(P / S)$. Milgrom and Roberts (1990) show that the concept of complementarity is directly related to supermodularity of the objective function. That is, a positive mixed partial derivative of a twice differentiable with respect to the two strategy variables indicates complementarity. More importantly, Milgrom and Roberts (1990) show that this concept also applies to binary strategy indicators in case they are defined over a sublattice. $^{13}$

Roughly put, this means imposing an order on each pairwise combination of the variables. We begin with the smallest element in the order $\{0,0\}$ which means here that neither CSR nor environmental innovation is done. Elements ranked higher in this order denoted as $\{1,0\}$ and

\footnotetext{
${ }^{12}$ The adoption approach can be traced back to the work of Arora and Gambardella (1990). They show that a positive covariance among a pair of activity variables indicate complementarity if the activity variables are conditioned on any other firm-specific characteristics. For an overview of empirical studies, please see Brynjolfsson and Milgrom (2013)

${ }^{13}$ See also Milgrom and Roberts (1995) for an overview on lattice theory and complementarity.
} 
$\{0,1\}$, represent either environmental innovation only or exclusive CSR engagement, respectively. Finally, the highest element in this order $\{1,1\}$ accounts for joint use of the two firm strategies. This order directly translates into the case of complementarity with continuously measurable variables. Putting it differently, this condition implies that adopting both strategies jointly leads to higher performance than adopting both in isolation, simply because the one increases the marginal returns of the other. Formally, the condition for supermodularity and complementarity reads as follows:

$$
f(1,0)+f(0,1) \leq f(1,1)+f(0,0),
$$

where $f($.$) represents the objective function, P / S$ in our case, see Milgrom and Roberts (1990). In what follows, we are interested in incorporating the strategy measures in a meaningful representation of an objective function to get reliable and unbiased estimates. Needless to say, special interest is paid to separate causality from underlying correlation.

Let $V_{i t}$ represent firm $i$ 's absolute market capitalisation in year $t$. The market capitalisation (or market value) is assumed to depend on the sum of the firm's physical assets $\left(A_{i t}\right)$ and intangible (knowledge) assets (hereinafter $K_{i t}$ ) so that $V_{i t}=V\left(A_{i t}, K_{i t}\right)$. Intangible knowledge is typically accounted for by a distributed lag representation of all past investments into $R \& D$ (Griliches 1981, among others ${ }^{14}$ ), namely $R \& D_{i t}, R \& D_{i t-1}, R \& D_{i t-2}, \ldots, R \& D_{i t-n}$ forming the firm's stock of productive knowledge. Assuming that patents are a noisy measurement of the past investments into $\mathrm{R} \& \mathrm{D}$ (say, $R \& D_{t-1}, R \& D_{t-2}, \ldots, R \& D_{t-n}$ ) as frequently done (see for instance Griliches 1979), it can be replaced by the number of patents hold by firm $i$ in year $t$ denoted by Patents P $_{i t}$ Note that patents are not the first best indicator of intangible assets. Patent protection cannot be granted for every invention or productive knowledge asset. In particular, patent protection as a way to protect intellectual property against the use of others is used not equally across different sectors and for different inventions, i.e. for product and process inventions (Levin et al. 1987). Thus, the propensity to patents is very likely to differ, so patents are a rather biased indicator of intangible assets, but an easily available one. Given our data, a much more serious problem is the non-availability of information on physical assets of firms. This, in combination with the problems associated with the measurement of intangible assets, motivates the use of lagged market capitalisation information to account for assets. Scaling market capitalisation by firms' total sales is a frequently used ${ }^{15}$ sizeindependent measurement for the firms' value created by each single dollar of sales - the price-to-sales ratio, henceforth $P / S_{i t}$. The resulting regression equation reads as follows:

$$
\ln \left(P / S_{i t}\right)=\beta_{0}+\beta_{p} \ln \left(P / S_{i t-1}\right)+\beta_{10} \text { Green }_{i t}+\beta_{01} \text { CSR }_{i t}+\beta_{11} \text { Both }_{i t}+C_{i t} \beta_{c}+\epsilon_{i t}
$$

where $\boldsymbol{C}_{i t}$ is a vector of controls, and $\epsilon_{i t}=u_{i}+e_{i t}$ with $u_{i}$ denoting firm-specific fixed effects and $e_{i t}$ an idiosyncratic error component. Green $n_{i t}$ accounts for the choice in favour of environmental innovation alone (i.e. without introducing CSR). $C S R_{i t}$ denotes that CSR is in

\footnotetext{
${ }^{14}$ See in particular the surveys by Griliches et al. (1986) and Griliches (1990).

${ }^{15}$ Comparable studies use measures like Tobin's q to relate environmental regulation or environmental innovation to firms' market value and financial performance, such as Dowell et al. (2000) or Konar and Cohen (2001).
} 
place alone while the dummy Both $_{i t}$ indicates that both strategies are introduced jointly so that no implementation of either strategy serves as the reference group so that $\beta_{00}$ is necessarily zero. Note that the price-to-sales ratio is measured as the end of the year value. Furthermore, the literature assumes rather a very short event window in which upcoming information on firms' CSR activities and environmental innovation affect the market value (see e.g. Cañón-de-Francia and Garcés-Ayerbe 2009). However, we assume a rather long event window of a whole year. This is simply due to data availability. In this sense, the key variables of interest, Green $_{i t}, C S R_{i t}$, and $B o t h_{i t}$ enter the model in the same year as the dependent variable. Needless to say, the strategy variables to introduce environmental innovation or to be active in CSR (and have it certified) cannot be considered strictly exogenous, as they are endogenous choices of firms that may dependent on firms' market value. If providing a credible signal for sustainability (by having certified CSR measures in places) really complements the investment in environmental $R \& D$ and translates in higher firm values, clever managers are likely aware of this issue. As good management is likely to be correlated with higher market values, omitting a control for management may cause the strategy variables to be biased, as management remains an unexplained error component and thus $\operatorname{cov}\left(\operatorname{Green}_{i t}, \in_{i t}\right) \neq 0, \operatorname{cov}\left(C S R, \in_{i t}\right) \neq 0$, and of course $\operatorname{cov}\left(\operatorname{Both}_{i t}, \in_{i t}\right) \neq 0$. Thus, the empirical model needs to handle the endogeneity of the main variables of interest. Using one-year lagged values of the key variables of interest to rule out potential problems of endogeneity does not help here as we assume a rather short-term event window in which upcoming information on CSR and environmental innovation can affect firms' market value.

Using lagged price-to-sales ratio information to control for physical and intangible assets does not come without any costs. The price of a dynamic panel specification is to use potentially predetermined and thus not strictly exogenous regressors. Especially the lagged dependent variable is likely to be correlated with current errors via its correlation with past ones, thus making the classical linear regression model inconsistent, even if $\epsilon_{i t}$, is not autocorrelated. Another problem arises as neither the lagged dependent variable allows controlling for all differences in the price-to-sales ratio across firms nor does the vector of controls $\left(\boldsymbol{C}_{i t}\right)$. These unexplained differences in the between dimension of the panel data (i.e. across firms) may be correlated with at least some of the regressors making their coefficient estimates biased. Several ways to deal with predetermined regressors have been proposed. Anderson and Hsiao (1981) propose the use of instrumental variable regressions where all variables (left-hand and right-hand side) enter the model in first differences so that firm-specific effects are eliminated (and thus their potential correlation with the regressors). The violation of the strict exogeneity assumption with respect to the lagged dependent variable is addressed by using instruments, for instance the lagged differences or a further lag of the variable in levels. As this estimator is considered relatively inefficient, another (and more frequently used) estimation approach has been developed by Arellano and Bond (1991). Their dynamic panel GMM estimator allows also the fixed effects to be correlated with the regressors and is more efficient as more information regarding the instrument is used. It is considered more efficient than the Anderson-Hsiao estimator, as it makes use of more moment conditions and more instruments. In particular, the Arellano-Bond dynamic panel data differenced GMM estimator uses all available lags as instruments. However, also the Arellano and Bond (1991) method is found to be imprecise and inefficient due to weak instruments problem associated with using lagged 
values to instrument the first-differenced variables. Blundell and Bond (1998) therefore propose to set further orthogonality conditions. This results in estimating a system of equations that consists of an equation in levels and one in first differences using lagged levels and lagged differences as instruments.

The results part will provide a more detailed discussion on the instruments and estimation techniques used based on the underlying properties of the available data, especially the binary character of the key explanatory variables and the lag of the price-to-sales ratio. The Appendix (see Table 9 and explanations) will also provide basic results for the AndersonHsiao estimator neglecting endogeneity of the key variables of interest.

\subsection{Choice of Variables}

\section{Dependent variable financial performance}

The results of empirical analysis on the relation of specific CSR activity on a specific FP strongly depend on how CSR and FP are measured (see Margolis et al. 2007): concerning CSR, if it is business related or not and regarding FP, if it is an accounting-based or a marketbased measurement (see Margolis et al. 2007). The stock market performance is taken into consideration for the market-based approach. Whereas accounting-based measurements include company internal financial data like return-on-equity (ROE) (see Margolis et al. 2007). Orlitzky et al. (2003) also differentiate between market-based as external market responses and accounting-based as internal efficiency financial performance measurement.

We analyse the effect of a joint implementation of environmental innovation and CSR on the financial performance of a firm. Innovation and CSR are both forward-looking management strategies. This approach calls for market-based measurement of financial performance, replicating the long-term and future-oriented perspective. Therefore, we use price-to-sales ratio $\left(P / S_{i t}\right)$ as a market-based way of measuring financial performance (see Pava and Krausz 1996, Orlitzky et al. 2003, Margolis et al. 2007). It reflects the value placed on sales by past performance, other companies or the market. The profit margin affects the price-to-sales ratio and therefore is a good indicator for market power. In our sample the $P / S$ variable shows a right-skewed distribution. Thus we use firm i's $P / S$ in logarithm.

\section{Explanatory and control variables}

In the A4 database, additional variables explaining the market power like market share or the Herfindahl index are not available. Especially the large firms indexed on the stock market in A4 are firms acting worldwide and therefore the usage of such market power indicators is questionable, as Aghion et al. (2005) point out. These indicators are limited concerning worldwide acting companies because the geographic market definition is unclear. Alternatives like the Lerner index (see e.g. Aghion et al. (2005) or price-to-cost ratio (see e.g. Gorodnichenko et al. 2010) are also not included in the A4 database. Nevertheless, the panel data structure allows controlling for unobservable but time consistent factors of market power. Nickell (1996) explains that changes of unobservable factors correlate with the changes of the observable variables. In our case the inclusion of the lagged P/S $\left(\operatorname{lag}(P / S)_{i t}\right)$ controls for these unobservable factors and at the same time it considers that past financial performance may explain current financial performance. 
Another explanatory variable for financial performance, especially from an investors' perspective and when measured by a market-based variable is a risk parameter. The risk coefficient beta as parameter for stocks' volatility, which measures the risk of an investment, reflects the riskiness of the returns of a firm. Several previous empirical analyses of CSR and financial performance criticise that risk, which might affect future financial performance, is not adequately taken into account (see Orlitzky 2005, Margolis et al. 2007, Cochran and Wood 1984). CSR can serve as a risk management instrument in the way that CSR engagement could lower a firm's risk (Husted 2005). Orlitzky and Benjamin (2001) provide evidence for this interlink of CSR and financial risk of a firm in their meta-analysis. Therefore, we include the variable beta $\left(\right.$ Beta $\left._{i t}\right)$ measuring the market risk, as an essential element when analysing the CSR-FP relationship.

Moreover, we have to control for business cycles' effects on stock market value. The development of stock market prices may differ across countries and time due to business cycles effects. Thus, we need a time trend control that varies across countries. This effect is assumed to have very immediate impact, so no time lag is included. In addition, it is reasonable to consider the business cycle as exogenous. Therefore, information on real GDP (growth) by country and year is linked to the A4 database based on firms' country affiliation and included as the control variable (GDP-Growth $h_{i t}$ ).

Patents are indicators for temporarily limited monopoly and a noisy measure for the stock of intangible assets. The company holding a patent has a technological advantage, which can be the reason for price differences resulting in a better performance. The benefit of the usage of US patents is their consistent measurement method and the relevancy of these patents. We use the logarithm number of real hold patents $\left(\ln (\text { Patents })_{i t}\right)$ by a company in the specific year from the A4 database for our calculations because we assume that the stock of patents affects $P / S$ in the same time period and is not time lagged.

Moreover, the age of a company might influence its financial performance either positively, e.g. by learning effects, or negatively due to their limits in adjusting to new challenges. Hopenhayn (1992) shows under which circumstances older firms can gain higher profits. Therefore, age is an important factor when measuring financial performance and we include the age of the company as the explanatory variable $\left(\ln (\text { Age })_{i t}\right)$.

Furthermore, we control for the size of the company measured by sales in logarithm form $\left(\ln (\text { Sales })_{i t}\right)$. The labour productivity of the company is included as number of employees by sales $(\ln ($ Labour/Sales $)$ it) in logarithm.

Additionally, to these traditional explanatory variables for financial performance, we focus on the effects of environmental innovation and CSR in our analysis.

\section{Environmental innovation}

Concerning the measurement of innovation, input and output of innovation can be differentiated. Smith (2005, p 151) discusses the traditional categorization of innovation into ideas, learning, creation of knowledge on the one hand and competence and capabilities on the other hand. In the Oslo Manual, innovation input is explained as investments, which include R\&D (see also Kleinknecht et al. 2002) and other innovation related investments. Furthermore, other kinds of preparation for different types of innovation like relationships to 
universities to deploy external knowledge can be treated as innovation input (OECD and European Commission 2005). In empirical literature R\&D expenditures are often taken as an input innovation variable, due to its long history of collection and the comparability between countries in contrast to other input innovation determinants (Kleinknecht et al. 2002, Smith 2005). ${ }^{16}$

In our approach we focus on voluntary action of a firm in the environmental context. Therefore, the appropriate innovation variable available in the A4 database is the dichotomous variable named environmental R\&D (EnvInno $\left.{ }_{i t}\right)$. It provides information on whether the firm invested in $R \& D$ related to environmentally friendly products and processes to reduce emission and resource consumption. This allows us to categorise environmentally innovating and non-environmentally innovating firms. Nonetheless, the dichotomous variable to measure innovation is rather rough, as especially for large companies it is not clear which efforts have been made and how this affects the environmental activity of the firm. However, as the A4 database does not provide further indicators on environmental innovation, this research is a first step to investigate how a specific CSR activity might support environmental R\&D. Current environmental $R \& D$ investments are an indicator for the future market value of a firm. However, this kind of innovation is not easily observable for customers, investors or other business partners. Hence, it is plausible to assume that CSR might help to overcome this information asymmetry in the case of environmental R\&D investment.

\section{CSR}

Our approach to the complementary character of CSR and environmental innovation is based on the consideration that CSR serves as a signal to stakeholders for environmentally friendly production. Firms' CSR activities are often self-reported and consumers are sceptical about them. Certification of third parties on the CSR activity of a company can serve as a signal and create credibility and therefore support the consumers, workers, investors, and trading partners in their decisions. Therefore, firms can gain benefits from spreading this information. This is in line with findings by Terlaak and King (2006), who apply the signalling theory to certified management standards to overcome information asymmetries resulting in competitive advantage.

In the A4 database, the CSR indicator related to our approach is the dichotomous variable Global Report Initiative $\left(C S R_{i t}\right)$. This variable reveals if the company publishes its CSR report according to the Global Report Initiative (GRI) guidelines and the variable serves as a proxy for firm's CSR performance. These guidelines are developed to standardize sustainability reporting and create transparency and comparability of companies around the world. The guidelines include over 100 very detailed indicators on firm's sustainability in the areas economic, environmental, social, and governance. Reports according to the GRI guidelines can be treated as a method of certification because the GRI reporting comprises detailed information and a third party ensures that the data is in accordance with the guidelines. Furthermore, the reports are publicly published and the data is available through the GRI database. Although the formulation of the indicator may only suggest if the firm reports according to the GRI guidelines and not if the firm is really engaged in CSR activities, we

\footnotetext{
${ }^{16}$ For a deeper discussion on R\&D as innovation input, please see e.g. Kleinknecht et al. (2002) or Smith (2005).
} 
assume that in practice only firms engaged in CSR activities report on them and in turn decide if they report in such detail as demanded by GRI. ${ }^{17}$

Our dichotomy variable combines the different CSR activities as it is an overarching indicator on the firm's CSR engagement. As such, the variable is a signal for the firms' social and environmental most common CSR definition in literature and practice, which includes all firm activities that integrate social and environmental concerns into business practices and that go beyond mere legal requirements. However, judging a company's social and environmental engagement by only one indicator is a rather crude measurement (see Cochran and Wood 1984 for a discussion on third-party rankings), particularly as these indicators are dichotomous variables which might not vary much over time. If a firm introduced CSR reporting according to the GRI guidelines once, the firm might not go a step backwards and abolish the external audition. Nevertheless, the data in the A4 database shows enough variation (see description above) for the estimation strategy. Though, in interpreting the results the rough measurement of CSR has to be taken into account.

Table 2 provides the overview of the chosen variables with a short explanation, together with the mean, the standard deviation, and the minimum and maximum values.

Table 2: Overview variables and descriptive statistics (6,737 observations)

\begin{tabular}{|c|c|c|c|}
\hline Variable & Definition & $\begin{array}{l}\text { Mean } \\
(\mathrm{SD})\end{array}$ & $\operatorname{Min} / \mathbf{M a x}$ \\
\hline $\ln (P / S)_{i t}$ & Logarithm of price-to-sales ratio & $\begin{array}{c}0.1759 \\
(0.9624)\end{array}$ & $-2.2964 / 2.9498$ \\
\hline $\ln (\text { Patents })_{i t}$ & $\begin{array}{l}\text { Hold US patents by company in } \\
\text { logarithm }\end{array}$ & $\begin{array}{c}0.5109 \\
(1.6150)\end{array}$ & 0/9.9739 \\
\hline Beta $_{i t}$ & Risk parameter beta & $\begin{array}{c}1.1060 \\
(0.6208)\end{array}$ & $-2.4691 / 6.6454$ \\
\hline GDP-Growth & $\begin{array}{l}\text { Real GDP growth by country and } \\
\text { year }\end{array}$ & $\begin{array}{c}0.0089 \\
(0.0277)\end{array}$ & $-0.0854 / 0.1270$ \\
\hline $\ln (\text { Age })_{i t}$ & Age of a company as logarithm & $\begin{array}{c}3.8521 \\
(0.9357)\end{array}$ & $1.2528 / 6.2851$ \\
\hline $\ln (\text { Sales })_{i t}$ & $\begin{array}{l}\text { Logarithm of sales for size of the } \\
\text { company }\end{array}$ & $\begin{array}{l}22.4038 \\
(1.3987)\end{array}$ & $18.0315 / 26.7973$ \\
\hline Ln(Labour/Sales $)_{i t}$ & $\begin{array}{l}\text { Labour productivity of company as } \\
\text { logarithm of employees by sales }\end{array}$ & $\begin{array}{l}-12.9804 \\
(0.9110)\end{array}$ & $-18.1888 /-9.4769$ \\
\hline EnvInno $_{i t}$ & $\begin{array}{l}\text { Dichotomous innovation variable } \\
\text { environmental R\&D }\end{array}$ & $\begin{array}{c}0.1542 \\
(0.3612)\end{array}$ & $0 / 1$ \\
\hline$C S R_{i t}$ & $\begin{array}{l}\text { Dichotomous CSR variable on CSR } \\
\text { reporting according to Global Report } \\
\text { Initiative guidelines }\end{array}$ & $\begin{array}{c}0.2228 \\
(0.4162)\end{array}$ & $0 / 1$ \\
\hline
\end{tabular}

\section{Results}

We conducted preliminary tests on fixed effects versus random effects models. As a first step, the F-test on the null hypothesis of no fixed effects is rejected. The Hausman-Test with the

\footnotetext{
${ }^{17}$ Please note, that on the long run the company would take unnecessary risk if it reports on CSR engagement, which turns out to be false or if the set targets are not reached.
} 
null hypothesis of no correlation was rejected, too. Therefore, we use a fixed-effects model with robust standard errors for the following dynamic panel estimations in a base model.

As a first step we estimate the model 1 with the logged growth in price-per-sales as dependent variable and without the complementary variables of our interest to test if the traditional variables explaining the growth in price-per-sales are in direction and size as expected from previous research (Table 3). The results verify that our dynamic approach including the one year time lag of price-per-sales $\left(\ln (\mathrm{P} / \mathrm{S})_{i t-1}\right)$ is appropriate due to high significance and size and direction comparable to previous studies. The high negative coefficient shows marginally decreasing growth rates in P/S. A one percent increase in the lagged price-to-sales ratio is significantly associated with a 0.83 percent smaller growth rate in the price-to-sales ratio between the periods $t$ and $t-1$. Or in other words, the higher the firm i's price-to-sales ratio already is, the lower are the rates of growth. Furthermore, risk $\left(\right.$ Beta $\left._{i t}\right)$ affects the P/S growth negatively as expected and is highly significant. The GDP growth (GDP-Growth ${ }_{i t}$ ) is highly significant and shows that the business cycles' effects varying across countries and time influence the stock market value (scaled by total sales) very strongly. Sales ( $\ln \left(\right.$ Sales) ${ }_{i t}$ ) affect the P/S growth significantly negatively. The variables productivity (In(Labour/Sales) $\left.)_{i t}\right)$, age $\left(\ln (\text { Age })_{i t}\right)$, and stock of patents $\left(\ln (\text { Patents })_{i t}\right)$ are not significant in our model 1.

Model 2 provides the results for the dependent variable in logarithm $\left(\ln (\mathrm{P} / \mathrm{S})_{i t}\right)$ according to the previously explained estimation strategy, which we also use in the further estimation models. Compared to the growth of $P / S_{i t}$ as a dependent variable, the lag of price-per-sales appears here with a positive effect, which shows that previous performance influences future performance positively and is exactly the value of the coefficient in the growth model 1 plus 1 , of course. The other coefficients are necessarily exactly the same in size and direction.

In the following, we concentrate on the exclusive variables environmental innovation $\left(E\right.$ Inno $\left.{ }_{i t}\right)$, CSR $\left(C S R_{i t}\right)$, and doing both strategies together $\left(B O T H_{i t}\right)$ by including them in the estimations. The additional variables do not change the basic model results.

Model 3 shows that a firm strategy of either doing environmental innovation or CSR alone has no significant impact on P/S. Implementing both strategies jointly reveals a highly positively significant effect on a firm's P/S. The firms that introduced both strategies jointly enjoy a 8.46 percent higher price-to-sales ratio compared to the control group, i.e. firms that neither engage in environmental R\&D activities nor in CSR. Based on our assumptions this suggests that reporting to the GRI guidelines might help to signal the pro-environmental action of firms. The one-sided t-test for complementarity against the null that EnvInno ${ }_{i t}+C S R_{i t}-B O T H_{i t} \geq 0$, supports complementarity. However, we can only reject the null hypothesis with a $90 \%$ probability, which would imply complementarity of environmental innovations and GRI as CSR activity, but the result might not hold for all industries or firms. 
Table 3: Estimation Results Base Models

\begin{tabular}{|c|c|c|c|}
\hline Dependent variable: & $\begin{array}{c}\text { (1) } \\
\text { FE robust } \\
\operatorname{gr}(\mathbf{P} / \mathrm{S})_{\text {it }} \\
\end{array}$ & $\begin{array}{c}(2) \\
\text { FE robust } \\
\ln (P / S)_{\text {it }} \\
\end{array}$ & $\begin{array}{c}(3) \\
\text { FE robust } \\
\ln (\mathbf{P} / \mathrm{S})_{\text {it }} \\
\end{array}$ \\
\hline $\ln (P / S)_{i t-1}$ & $\begin{array}{c}-0.830 * * * \\
(0.0236)\end{array}$ & $\begin{array}{l}0.170 * * * \\
(0.0236)\end{array}$ & $\begin{array}{c}0.166^{* * *} \\
(0.0235)\end{array}$ \\
\hline Beta $_{i t}$ & $\begin{array}{c}-0.233 * * * \\
(0.0326)\end{array}$ & $\begin{array}{c}-0.233^{* * *} \\
(0.0326)\end{array}$ & $\begin{array}{c}-0.232 * * * \\
(0.0326)\end{array}$ \\
\hline GDP-Growth $_{i t}$ & $\begin{array}{c}3.460 * * * \\
(0.626)\end{array}$ & $\begin{array}{c}3.460 * * * \\
(0.626)\end{array}$ & $\begin{array}{c}3.492 * * * \\
(0.623)\end{array}$ \\
\hline $\ln (\text { Sales })_{i t}$ & $\begin{array}{c}-0.474 * * * \\
(0.0441)\end{array}$ & $\begin{array}{c}-0.474 * * * \\
(0.0441)\end{array}$ & $\begin{array}{c}-0.476^{* * *} \\
(0.0441)\end{array}$ \\
\hline $\ln (\text { Labour/Sales })_{i t}$ & $\begin{array}{l}-0.0567 \\
(0.0430)\end{array}$ & $\begin{array}{l}-0.0567 \\
(0.0430)\end{array}$ & $\begin{array}{l}-0.0545 \\
(0.0428)\end{array}$ \\
\hline $\ln (\text { Patents })_{i t}$ & $\begin{array}{c}0.00244 \\
(0.00517)\end{array}$ & $\begin{array}{c}0.00244 \\
(0.00517)\end{array}$ & $\begin{array}{c}0.00237 \\
(0.00514)\end{array}$ \\
\hline $\ln (\text { Age })_{i t}$ & $\begin{array}{l}-0.0781 \\
(0.105)\end{array}$ & $\begin{array}{l}-0.0781 \\
(0.105)\end{array}$ & $\begin{array}{l}-0.0715 \\
(0.104)\end{array}$ \\
\hline EnvInno $_{i t}$ & & & $\begin{array}{l}0.00688 \\
(0.0261)\end{array}$ \\
\hline$C S R_{i t}$ & & & $\begin{array}{c}0.0285 \\
(0.0204)\end{array}$ \\
\hline$B O T H_{i t}$ & & & $\begin{array}{c}0.0846^{* * *} \\
(0.0280)\end{array}$ \\
\hline Constant & $\begin{array}{c}10.54 * * * \\
(0.967)\end{array}$ & $\begin{array}{c}10.54 * * * \\
(0.967)\end{array}$ & $\begin{array}{c}10.56^{* * *} \\
(0.966)\end{array}$ \\
\hline Observations & 6,737 & 6,737 & 6,737 \\
\hline $\begin{array}{l}\mathrm{R}^{2} \text { within } \\
\text { Rho }\end{array}$ & $\begin{array}{l}0.620 \\
0.819\end{array}$ & $\begin{array}{l}0.532 \\
0.819\end{array}$ & $\begin{array}{l}0.533 \\
0.818\end{array}$ \\
\hline \multicolumn{4}{|c|}{ Test for complementarity: $\mathrm{H}_{0}$ (full test): $E n v I n n o_{i t}+C S R_{i t}-B O T H_{i t} \geq 0$} \\
\hline $\begin{array}{l}\text { Test Statistic } \\
\text { p-value }\end{array}$ & & & $\begin{array}{c}2.10 \\
0.0736 \\
\end{array}$ \\
\hline $\begin{array}{l}\text { Note: The model includes four joi } \\
\text { parentheses. } \\
* * * p<0.01, * * p<0.05, * p<0.1\end{array}$ & ar dummies. & standard & \\
\hline
\end{tabular}

In the following, we apply GMM models to further explore the complementarity of the firm strategies of environmental innovation and CSR. The inclusion of the lagged dependent variable in the models 1-3 might violate the strict exogeneity assumption as explained above. Furthermore, the management decision on doing environmental innovation or engage in CSR might also be endogenous. As the database does not provide adequate instruments, we estimate models with a dynamic GMM approach suggested by Arellano and Bond (1991). These types of models use estimations in differences which allows applying lags as instruments (Table 4). The model is based on a two-step GMM procedure to yield more efficient, i.e. heteroscedasticity robust estimates. As such, models 4-6 include as instrumentation vector the controls $\boldsymbol{C}_{i t}$ as differences. The potentially endogenous variable $\ln (P / S)_{i t-1}$ is instrumented by the second and any further time lags. The variables EnvInno $i t$, $C S R_{i t}, B O T H_{i t}$ are instrumented by the first and any further time lags in model 4, or the moving average in model 5 , and both - the first and further time lags as well as the moving average - in model 6 . 
Table 4: Estimation Results GMM Models

\begin{tabular}{|c|c|c|c|}
\hline Dependent variable: & $\begin{array}{c}(4) \\
\text { GMM } \\
\ln (\mathbf{P} / \mathrm{S})_{\text {it }}\end{array}$ & $\begin{array}{c}(5) \\
\text { GMM } \\
\ln (\mathbf{P} / \mathrm{S})_{\text {it }}\end{array}$ & $\begin{array}{c}\text { (6) } \\
\text { GMM } \\
\ln (\mathbf{P} / \mathrm{S})_{\text {it }}\end{array}$ \\
\hline $\ln (P / S)_{i t-1}$ & $\begin{array}{l}0.391 * * * \\
(0.0491)\end{array}$ & $\begin{array}{l}0.409 * * * \\
(0.0474)\end{array}$ & $\begin{array}{l}0.366 * * * \\
(0.0435)\end{array}$ \\
\hline Beta $_{i t}$ & $\begin{array}{l}-0.146^{* * *} \\
(0.0346)\end{array}$ & $\begin{array}{l}-0.141 * * * \\
(0.0348)\end{array}$ & $\begin{array}{c}-0.133^{* * *} \\
(0.0356)\end{array}$ \\
\hline GDP-Growth & $\begin{array}{l}1.640 * * \\
(0.755)\end{array}$ & $\begin{array}{l}1.606 * * \\
(0.784)\end{array}$ & $\begin{array}{l}1.808^{* *} \\
(0.774)\end{array}$ \\
\hline $\ln (\text { Sales })_{i t}$ & $\begin{array}{c}-0.576^{* * * *} \\
(0.0478)\end{array}$ & $\begin{array}{c}-0.594^{* * *} \\
(0.0473)\end{array}$ & $\begin{array}{l}-0.581^{* * *} \\
(0.0457)\end{array}$ \\
\hline $\ln (\text { Labour/Sales })_{i t}$ & $\begin{array}{l}-0.111^{* *} \\
(0.0449)\end{array}$ & $\begin{array}{c}-0.130 * * * \\
(0.0487)\end{array}$ & $\begin{array}{l}-0.134 * * * \\
(0.0465)\end{array}$ \\
\hline $\ln (\text { Patents })_{i t}$ & $\begin{array}{l}0.000697 \\
(0.00547)\end{array}$ & $\begin{array}{l}-0.000447 \\
(0.00548)\end{array}$ & $\begin{array}{l}-0.00294 \\
(0.00544)\end{array}$ \\
\hline $\ln (\text { Age })_{i t}$ & $\begin{array}{c}0.0837 \\
(0.0932)\end{array}$ & $\begin{array}{c}0.0784 \\
(0.0956)\end{array}$ & $\begin{array}{c}0.0541 \\
(0.0996)\end{array}$ \\
\hline EnvInno $_{i t}$ & $\begin{array}{l}-0.00337 \\
(0.0409)\end{array}$ & $\begin{array}{c}-0.0826 * * \\
(0.0359)\end{array}$ & $\begin{array}{l}-0.0335^{*} \\
(0.0189)\end{array}$ \\
\hline$C S R_{i t}$ & $\begin{array}{l}-0.0590 \\
(0.0444)\end{array}$ & $\begin{array}{c}0.0118 \\
(0.0246)\end{array}$ & $\begin{array}{l}0.00903 \\
(0.0180)\end{array}$ \\
\hline $\mathrm{BOTH}_{i t}$ & $\begin{array}{c}0.114^{*} \\
(0.0613)\end{array}$ & $\begin{array}{c}0.0166 \\
(0.0345)\end{array}$ & $\begin{array}{l}0.0470^{*} \\
(0.0270)\end{array}$ \\
\hline Observations & 6,737 & 6,737 & 6,737 \\
\hline Instruments & $\begin{array}{l}\text { 2-year and any } \\
\text { further lags of } \\
\ln (\mathrm{P} / \mathrm{S})_{i t} \text {, } \\
\text { 1-year and any } \\
\text { further lags of } \\
\text { EnviInno }_{i t}, \\
\mathrm{CSR}_{i t}, \text { BOTH }_{i t}\end{array}$ & $\begin{array}{l}\text { 2-year and any } \\
\text { further lags of } \\
\ln (\mathrm{P} / \mathrm{S})_{i t,}, \\
\text { moving } \\
\text { average of } \\
\text { EnvInno }_{i t}, \\
\mathrm{CSR}_{i t}, \text { BOTH }_{i t}\end{array}$ & $\begin{array}{c}\text { 2-year and any } \\
\text { further lags of } \\
\ln (\mathrm{P} / \mathrm{S})_{i t}, \\
\text { 1-year and any } \\
\text { further lags and } \\
\text { moving average of } \\
\text { EnvInno }_{t}, \mathrm{CSR}_{i t}, \\
\text { BOTH }_{i t}\end{array}$ \\
\hline $\begin{array}{l}\text { Arellano-Bond test for AR(1) in first } \\
\text { differences }\end{array}$ & 0.000 & 0.000 & 0.000 \\
\hline $\begin{array}{l}\text { Arellano-Bond test for } \mathrm{AR}(2) \text { in first } \\
\text { differences }\end{array}$ & 0.713 & 0.636 & 0.775 \\
\hline \multicolumn{4}{|c|}{ Sargan-Hansen test: 2-year and any further lags of $\ln (P / S)_{i t}$} \\
\hline Excluding group & 0.041 & 0.000 & 0.102 \\
\hline Difference & 0.000 & 0.000 & 0.000 \\
\hline \multicolumn{4}{|c|}{ Sargan-Hansen test: 1-year and any further lags of EnvInno ${ }_{i t}$ CSR $_{i t}$, and BOTH } \\
\hline Excluding group & 0.000 & & 0.000 \\
\hline Difference & 0.025 & & 0.990 \\
\hline \multicolumn{4}{|c|}{ Sargan-Hansen test: moving average of EnvInno ${ }_{i t}, C R_{i t}$, and $B O T H_{i t}$} \\
\hline Excluding group & & 0.000 & 0.000 \\
\hline Difference & & 0.001 & 0.714 \\
\hline \multicolumn{4}{|c|}{ Test for complementarity: $\mathrm{H}_{0}$ (full test): EnvInno $_{i t}+C S R_{i t}-B O T H_{i t} \geq 0$} \\
\hline $\begin{array}{l}\text { Test Statistic } \\
\text { p-value }\end{array}$ & $\begin{array}{c}10.10 \\
0.0007\end{array}$ & $\begin{array}{c}5.17 \\
0.0115\end{array}$ & $\begin{array}{c}5.28 \\
0.0108\end{array}$ \\
\hline \multicolumn{4}{|c|}{$\begin{array}{l}\text { Note: The model includes four jointly-significant year dummies. Robust standard errors in } \\
\text { parentheses. } \\
* * * p<0.01, * * p<0.05, * p<0.1\end{array}$} \\
\hline
\end{tabular}

Compared to the model 3, the GMM estimation in model 4 shows smaller coefficients, except for the lagged P/S, and in some cases lower significance levels for the traditional variables influencing $\mathrm{P} / \mathrm{S}$. Nevertheless, the directions are comparable to the previous results. The 
coefficient estimates of the variables of interest, environmental innovation and CSR, are again not statistically different from zero (however, their sign is now negative). Concerning engagement in both strategies jointly $\left(\mathrm{BOTH}_{i t}\right)$, model 4 confirms the results from the basic models as there is a positive effect on P/S but only significant at the $10 \%$ level. The test developed by Arellano and Bond (1991) for auto-correlation in an auto-regressive process of the first order (AR1) shows significant serial correlation, but no significant evidence of serial correlation in the first-differenced errors at order two $(\mathrm{p}=0.713)$, which allows us to use lags higher than two as instruments. The Sargan-Hansen test for over-identification against the null - that the vector of instruments is orthogonal to the vector of the errors (or against the null that the instruments are exogenous) - shows that the instrumentation of the variable $\ln (P / S)_{i t-1}$ is not strictly exogenous $(\mathrm{p}=0.000)$. Unfortunately, the database does not provide better instruments and also estimations and tests with longer time lags reveal the same endogeneity problem. Therefore, we have to interpret the results with care. Although formal endogeneity is observable, it might not strongly affect the market value during the next year in reality as the $\mathrm{P} / \mathrm{S}$ is a year-end value. The tests for the subset of instruments with the lags of EnvInno ${ }_{i t}$, $C S R_{i t}, B O T H_{i t}$ confirm exogeneity slighty over the $1 \%$ level. This might indicate that the strict exogeneity assumption could be violated.

Therefore, we use the moving averages as instruments instead for the innovation and CSR variables as instruments in model 5. For the moving average we calculated the average of the sum of the current, one year, and two year time lag for each of the variables EnvInno ${ }_{i t}, C R_{i t}$, $B O T H_{i t}$. In this model the traditional variables are similar to model 4, except for the coefficient estimate of the stock of patents ( $\ln$ (Patents) it $_{\text {( }}$ which is in all models not significant. The variables of a pure CSR strategy and a joint CSR and R\&D strategy are not significant. However, now environmental R\&D affects P/S significantly negative (5\% level) but only with a small coefficient. Again the Arellano-Bond test at order one shows significant serial correlation, but no significant evidence of serial correlation in the first-differenced errors at order two $(\mathrm{p}=0.636)$. The null hypothesis of exogeneity of the subsets of instruments has to be rejected at the conventional 10 or $5 \%$ levels for both subsets.

Hence, we estimate the model 6 including all instruments, the instrument of $\ln (P / S)_{i t-1}$ and the of the variables EnvInno $i t, C S R_{i t}, B O T H_{i t}$. Again the instrument of $\ln (P / S)_{i t-1}$ is object to endogeneity. The instruments for our variables of concern show in model 6 that they are exogenous at the $5 \%(p=0.051)$ or the $10 \%$ level $(p=0.344)$ and would imply that they are appropriate instruments. Related to the previous fixed-effects estimations and the model 3 results in combination with the tests on exogeneity of the instruments, model 6 seems the best available estimation strategy for our data. The results for the estimations in model 6 approve mostly the previous results in direction and values. Here like in model 5 the variable patents $\left.(\ln \text { (Patents) })_{i t}\right)$ is negative, but like in the other models not significant. The focus of our research lies in the variables for innovation, CSR and their joint implementation. Model 6 shows again a positive effect of doing both strategies (innovation and CSR) together and this time the coefficient estimate is significant at the $10 \%$ level. The value is comparable to the other models. Thus, with the moving average as instruments the joint innovation-CSR strategy gets significant and the size of coefficient estimate is also close the previous models. Concerning the complementarity we test whether condition (1) holds. We can reject the null with $98 \%$ or higher in all GMM models. This implies complementarity of environmental 
R\&D and CSR. All models confirm complementarity of environmental innovation and CSR in form of reporting according through the GRI guidelines.

Nevertheless, as the instruments in our models are restricted and might violate the strict exogeneity assumption, further robustness checks are needed to verify the results so far. Furthermore, the sample includes a huge number of firms in the service sector which questions if it is appropriate to test environmental innovation activity and its possible disclosure via CSR, and if other CSR variables than GRI reporting might serve as better signal for environmental R\&D. Therefore, we run further robustness checks addressing these possible drawbacks of our models which are the objectives in the next section.

\section{Robustness Checks}

In a first robustness check, the sample is restricted to only the manufacturing industries (see shaded area in Table 7). This limits our sample to 2,878 observation and 820 firms observed for the years 2005 to 2009. Running the same models as with the full sample leads to following estimation results. 
Table 5: Estimation Results GMM Models for Manufacturing Industries

\begin{tabular}{|c|c|c|c|c|}
\hline Dependent variable: & $\begin{array}{c}(8) \\
\text { FE robust } \\
\ln (\mathbf{P} / \mathrm{S})_{\text {it }} \\
\end{array}$ & $\begin{array}{c}\text { (9) } \\
\text { GMM } \\
\ln (\mathbf{P} / S)_{\text {it }} \\
\end{array}$ & $\begin{array}{c}\text { (10) } \\
\text { GMM } \\
\ln (\mathbf{P} / S)_{\text {it }} \\
\end{array}$ & $\begin{array}{c}(11) \\
\text { GMM } \\
\ln (\mathbf{P} / S)_{\text {it }} \\
\end{array}$ \\
\hline $\ln (P / S)_{i t-1}$ & $\begin{array}{c}0.111 * * * \\
(0.0322)\end{array}$ & $\begin{array}{c}0.287 * * * \\
(0.0786)\end{array}$ & $\begin{array}{c}0.350 * * * \\
(0.0724)\end{array}$ & $\begin{array}{l}0.292 * * * \\
(0.0683)\end{array}$ \\
\hline Beta $_{i t}$ & $\begin{array}{c}-0.197 * * * \\
(0.0461)\end{array}$ & $\begin{array}{l}-0.111^{* *} \\
(0.0447)\end{array}$ & $\begin{array}{l}-0.107 * * \\
(0.0450)\end{array}$ & $\begin{array}{l}-0.102^{* *} \\
(0.0415)\end{array}$ \\
\hline GDP-Growth $_{i t}$ & $\begin{array}{c}3.005 * * * \\
(0.977)\end{array}$ & $\begin{array}{l}2.188^{*} \\
(1.302)\end{array}$ & $\begin{array}{l}2.346^{*} \\
(1.356)\end{array}$ & $\begin{array}{l}2.423^{*} \\
(1.311)\end{array}$ \\
\hline $\ln (\text { Sales })_{i t}$ & $\begin{array}{c}-0.434 * * * \\
(0.0917)\end{array}$ & $\begin{array}{c}-0.532 * * * \\
(0.0876)\end{array}$ & $\begin{array}{c}-0.563 * * * \\
(0.0974)\end{array}$ & $\begin{array}{c}-0.596 * * * \\
(0.0903)\end{array}$ \\
\hline $\ln (\text { Labour/Sales })_{i t}$ & $\begin{array}{c}-0.122 \\
(0.0775)\end{array}$ & $\begin{array}{c}-0.142 \\
(0.0875)\end{array}$ & $\begin{array}{l}-0.175 \\
(0.109)\end{array}$ & $\begin{array}{l}-0.190^{*} \\
(0.0969)\end{array}$ \\
\hline $\ln (\text { Patents })_{i t}$ & $\begin{array}{c}0.00259 \\
(0.00602)\end{array}$ & $\begin{array}{l}-1.99 \mathrm{e}-05 \\
(0.00627)\end{array}$ & $\begin{array}{l}-0.00371 \\
(0.00665)\end{array}$ & $\begin{array}{l}-0.00455 \\
(0.00678)\end{array}$ \\
\hline $\ln (\mathrm{Age})_{i t}$ & $\begin{array}{l}-0.190 \\
(0.168)\end{array}$ & $\begin{array}{c}0.149 \\
(0.146)\end{array}$ & $\begin{array}{c}0.100 \\
(0.146)\end{array}$ & $\begin{array}{c}0.169 \\
(0.151)\end{array}$ \\
\hline EnvInno $_{i t}$ & $\begin{array}{c}0.0140 \\
(0.0320)\end{array}$ & $\begin{array}{l}-0.0160 \\
(0.0437)\end{array}$ & $\begin{array}{c}-0.0805 * * \\
(0.0406)\end{array}$ & $\begin{array}{l}-0.0366 \\
(0.0240)\end{array}$ \\
\hline$C S R_{i t}$ & $\begin{array}{c}0.0176 \\
(0.0285)\end{array}$ & $\begin{array}{l}-0.134 * * \\
(0.0613)\end{array}$ & $\begin{array}{c}0.0127 \\
(0.0432)\end{array}$ & $\begin{array}{l}0.00599 \\
(0.0265)\end{array}$ \\
\hline $\mathrm{BOTH}_{i t}$ & $\begin{array}{c}0.0488 \\
(0.0382)\end{array}$ & $\begin{array}{c}0.000594 \\
(0.0925)\end{array}$ & $\begin{array}{l}-0.0221 \\
(0.0512)\end{array}$ & $\begin{array}{c}0.0103 \\
(0.0347)\end{array}$ \\
\hline Constant & $\begin{array}{c}9.257 * * * \\
(2.092)\end{array}$ & & & \\
\hline Observations & 2,878 & 2,878 & 2,878 & 2,878 \\
\hline $\begin{array}{l}\mathrm{R}^{2} \\
\text { Rho }\end{array}$ & $\begin{array}{l}0.531 \\
0.841 \\
\end{array}$ & & & \\
\hline Instruments & & $\begin{array}{l}\text { 2-year and any } \\
\text { further lags of } \\
\ln (\mathrm{P} / \mathrm{S})_{i t} \text {, } \\
\text { 1-year and any } \\
\text { further lags of } \\
\text { EnvInno }_{t} \text { CSR }_{i t} \text {, } \\
\text { BOTH }_{i t}\end{array}$ & $\begin{array}{l}\text { 2-year and any } \\
\text { further lags of } \\
\ln (\mathrm{P} / \mathrm{S})_{i t}, \\
\text { moving average of } \\
\text { EnvInno }_{i t}, \mathrm{CSR}_{i t}, \\
\text { BOTH }_{i t}\end{array}$ & $\begin{array}{l}\text { 2-year and any } \\
\text { further lags of } \\
\ln (\mathrm{P} / \mathrm{S})_{i t} \text {, } \\
\text { 1-year and any } \\
\text { further lags and } \\
\text { moving average of } \\
\text { EnvInno }_{i t}, \text { CSR }_{i t}, \\
\text { BOTH }_{i t}\end{array}$ \\
\hline $\begin{array}{l}\text { Arellano-Bond test } \\
\text { for AR(1) in first } \\
\text { differences }\end{array}$ & & 0.000 & 0.000 & 0.000 \\
\hline $\begin{array}{l}\text { Arellano-Bond test } \\
\text { for } A R(2) \text { in first } \\
\text { differences }\end{array}$ & & 0.0639 & 0.0141 & 0.0248 \\
\hline \multicolumn{5}{|c|}{ Sargan-Hansen test: 2-year and any further lags of $\ln (P / S)_{i t}$} \\
\hline Excluding group & & 0.526 & 0.011 & 0.541 \\
\hline Difference & & 0.000 & 0.000 & 0.000 \\
\hline \multicolumn{5}{|c|}{ Sargan-Hansen test: 1-year and any further lags of EnvInno ${ }_{i t}, \mathrm{CSR}_{i t}$, and $\mathrm{BOTH}_{i t}$} \\
\hline Excluding group & & 0.000 & & 0.000 \\
\hline Difference & & 0.921 & & 0.998 \\
\hline \multicolumn{5}{|c|}{ Sargan-Hansen test: moving average of EnvInno ${ }_{i t}, C_{i t}$, and $\mathrm{BOTH}_{i t}$} \\
\hline $\begin{array}{l}\text { Excluding group } \\
\text { Difference }\end{array}$ & & & $\begin{array}{l}0.000 \\
0.300\end{array}$ & $\begin{array}{l}0.000 \\
0.503\end{array}$ \\
\hline \multicolumn{5}{|c|}{ Test for complementarity: $\mathrm{H}_{0}$ (full test): $E n v I n n o_{i t}+C S R_{i t}-B O T H_{i t} \geq 0$} \\
\hline $\begin{array}{l}\text { Test Statistic } \\
\text { p-value }\end{array}$ & $\begin{array}{c}0.15 \\
0.3472\end{array}$ & $\begin{array}{c}4.76 \\
0.0146\end{array}$ & $\begin{array}{c}0.78 \\
0.1890\end{array}$ & $\begin{array}{c}1.02 \\
0.1569\end{array}$ \\
\hline
\end{tabular}


Also with the restricted sample of only including the manufacturing industry, the estimation models confirm the previous effects of the traditional explanatory variables. Although the instruments seem to work better in the restricted sample, the effects of the variables of interest are not in a clear direction when comparing the different models. Furthermore, the complementarity test would rather imply no complementarity. This would imply for our hypothesis that the firm's GRI reporting is a rather poor signal for CSR in the manufacturing sector. However, the descriptive analysis shows that in some of the manufacturing industries both strategies are implemented at the same time. Additional data especially on sectors with environmental $R \& D$ activity would be needed to verify results and reveal for which sectors CSR reporting might serve as a signal for their clients.

Another critical point is the choice of GRI as CSR variable. As mentioned above, this indicator is just a rough measurement of firm's CSR activity as it is a dichotomous variable. A further limit might be that the indicator only tells us if the firm reports according to the GRI guidelines, which does not necessarily reveal much about the specific activities. As the A4 database provides mainly dichotomous indicators, which are suitable for our research focus, we cannot overcome most of these concerns. Nevertheless, in order to assess whether also other CSR indicators might serve as a signal for environmental R\&D or if the results are dependent of the choice of CSR variable, like Margolis et al. (2007) and Orlitzky et al. (2003) stress, is the objective of the following robustness check.

For this purpose we use the variable Sustainability External Audit (CSR $\left.R_{i t}\right)$. This variable reveals if the company has an external auditor of its CSR/Sustainability report. As such the variable could signal the firms' social and environmental CSR activities. 
Table 6: Estimation Results GMM Models for CSR variable Sustainability External Audit

\begin{tabular}{|c|c|c|c|c|}
\hline Dependent variable: & $\begin{array}{c}(12) \\
\text { FE robust } \\
\ln (\mathrm{P} / \mathrm{S}) \mathrm{it}\end{array}$ & $\begin{array}{c}\text { (13) } \\
\text { GMM } \\
\ln (\mathrm{P} / \mathrm{S}) \mathrm{it}\end{array}$ & $\begin{array}{c}\text { (14) } \\
\text { GMM } \\
\ln (\mathrm{P} / \mathrm{S}) \mathrm{it}\end{array}$ & $\begin{array}{c}\text { (15) } \\
\text { GMM } \\
\ln (\mathrm{P} / \mathrm{S}) \mathrm{it}\end{array}$ \\
\hline$\overline{\operatorname{lag}-\ln (P / S)_{i t}}$ & $\begin{array}{c}0.168 * * * \\
(0.0235)\end{array}$ & $\begin{array}{c}0.390 * * * \\
(0.0477)\end{array}$ & $\begin{array}{c}0.430 * * * \\
(0.0469)\end{array}$ & $\begin{array}{c}0.391 * * * \\
(0.0465)\end{array}$ \\
\hline Beta $_{i t}$ & $\begin{array}{c}-0.232 * * * \\
(0.0326)\end{array}$ & $\begin{array}{c}-0.160^{* * *} \\
(0.0353)\end{array}$ & $\begin{array}{c}-0.153 * * * \\
(0.0361)\end{array}$ & $\begin{array}{c}-0.152 * * * \\
(0.0365)\end{array}$ \\
\hline GDP-Growth & $\begin{array}{c}3.485^{* * *} \\
(0.623)\end{array}$ & $\begin{array}{l}1.390 * \\
(0.783)\end{array}$ & $\begin{array}{l}1.351^{*} \\
(0.775)\end{array}$ & $\begin{array}{c}1.576 * * \\
(0.799)\end{array}$ \\
\hline $\ln (\text { Sales })_{i t}$ & $\begin{array}{c}-0.474 * * * \\
(0.0443)\end{array}$ & $\begin{array}{c}-0.595^{* * *} \\
(0.0477)\end{array}$ & $\begin{array}{c}-0.612^{* * *} \\
(0.0479)\end{array}$ & $\begin{array}{c}-0.603^{* * *} \\
(0.0461)\end{array}$ \\
\hline $\ln (\text { Labour/Sales })_{i t}$ & $\begin{array}{l}-0.0565 \\
(0.0431)\end{array}$ & $\begin{array}{l}-0.106 * * \\
(0.0445)\end{array}$ & $\begin{array}{c}-0.126 * * * \\
(0.0470)\end{array}$ & $\begin{array}{c}-0.119 * * * \\
(0.0455)\end{array}$ \\
\hline $\ln (\text { Patents })_{i t}$ & $\begin{array}{c}0.00248 \\
(0.00516)\end{array}$ & $\begin{array}{c}0.00235 \\
(0.00558)\end{array}$ & $\begin{array}{l}-0.000962 \\
(0.00568)\end{array}$ & $\begin{array}{c}0.00104 \\
(0.00566)\end{array}$ \\
\hline $\ln (\text { Age })_{i t}$ & $\begin{array}{l}-0.0780 \\
(0.104)\end{array}$ & $\begin{array}{c}0.0866 \\
(0.0949)\end{array}$ & $\begin{array}{c}0.109 \\
(0.0974)\end{array}$ & $\begin{array}{l}0.0885 \\
(0.102)\end{array}$ \\
\hline EnvInno $_{i t}$ & $\begin{array}{c}0.0264 \\
(0.0251)\end{array}$ & $\begin{array}{c}-0.0450 \\
(0.0564)\end{array}$ & $\begin{array}{c}-0.0560 \\
(0.0393)\end{array}$ & $\begin{array}{c}-0.0154 \\
(0.0197)\end{array}$ \\
\hline$C S R_{i t}$ & $\begin{array}{c}-0.00980 \\
(0.0276)\end{array}$ & $\begin{array}{c}-0.0211 \\
(0.0509)\end{array}$ & $\begin{array}{l}0.00375 \\
(0.0351)\end{array}$ & $\begin{array}{l}0.00390 \\
(0.0210)\end{array}$ \\
\hline $\mathrm{BOTH}_{\text {it }}$ & $\begin{array}{c}0.0443 \\
(0.0312)\end{array}$ & $\begin{array}{c}0.0186 \\
(0.0744)\end{array}$ & $\begin{array}{c}-0.0449 \\
(0.0423)\end{array}$ & $\begin{array}{r}-0.00942 \\
(0.0302)\end{array}$ \\
\hline Constant & $\begin{array}{c}10.54 * * * \\
(0.969)\end{array}$ & & & \\
\hline Observations & 6,737 & 6,737 & 6,737 & 6,737 \\
\hline $\begin{array}{l}\mathrm{R}^{2} \\
\text { Rho }\end{array}$ & $\begin{array}{l}0.533 \\
0.819\end{array}$ & & & \\
\hline Instruments & & $\begin{array}{l}\text { 2-year and any } \\
\text { further lags of } \\
\qquad \ln (\mathrm{P} / \mathrm{S})_{i t} \text {, } \\
\text { 1-year and any } \\
\text { further lags of } \\
\text { Envinno } \\
\text { CSR }_{i t}, \text { BOTH }_{i t}\end{array}$ & $\begin{array}{l}\text { 2-year and any } \\
\text { further lags of } \\
\ln (\mathrm{P} / \mathrm{S})_{i t}, \\
\text { moving average } \\
\text { of EnvInno } \\
\text { CSR }_{i t}, \text { BOTH }_{i t}\end{array}$ & $\begin{array}{l}\text { 2-year and any } \\
\text { further lags of } \\
\qquad \ln (\mathrm{P} / \mathrm{S})_{i t} \text {, } \\
\text { 1-year and any } \\
\text { further lags and } \\
\text { moving average } \\
\text { of EnvInno } \text { En }_{i t} \\
\text { CSR }_{i t}, \text { BOTH }_{i t}\end{array}$ \\
\hline $\begin{array}{l}\text { Arellano-Bond test for AR(1) in } \\
\text { first differences }\end{array}$ & & 0.000 & 0.000 & 0.000 \\
\hline $\begin{array}{l}\text { Arellano-Bond test for } \mathrm{AR}(2) \text { in } \\
\text { first differences }\end{array}$ & & 0.750 & 0.540 & 0.679 \\
\hline \multicolumn{5}{|c|}{ Sargan-Hansen test: 2-year and any further lags of $\ln (P / S)_{i t}$} \\
\hline Excluding group & & & 0.000 & 0.003 \\
\hline Difference & & & 0.000 & 0.000 \\
\hline \multicolumn{5}{|c|}{ Sargan-Hansen test: 1-year and any further lags of EnvInno ${ }_{i t}, C_{S R}$, and $B O T H_{i t}$} \\
\hline Excluding group & & & & 0.000 \\
\hline Difference & & & & 0.681 \\
\hline \multicolumn{5}{|c|}{ Sargan-Hansen test: moving average of EnvInno ${ }_{i t}, C R_{i t}$, and $\mathrm{BOTH}_{i t}$} \\
\hline $\begin{array}{l}\text { Excluding group } \\
\text { Difference }\end{array}$ & & & $\begin{array}{l}0.000 \\
0.004\end{array}$ & $\begin{array}{l}0.000 \\
0.453\end{array}$ \\
\hline \multicolumn{5}{|c|}{ Test for complementarity: $\mathrm{H}_{0}$ (full test): EnvInno $_{i t}+C S R_{i t}-B O T H_{i t} \geq 0$} \\
\hline $\begin{array}{lc}\text { Test Statistic } & 0.53 \\
\text { p-value } & 0.2339\end{array}$ & & & $\begin{array}{c}0.02 \\
0.4407\end{array}$ & $\begin{array}{c}0.00 \\
0.4766\end{array}$ \\
\hline
\end{tabular}


The traditional explanatory variables confirm the results of the previous models with the GRI reporting as CSR variable. However, the models 12-15 with the Sustainability External Audit as CSR variable show different effects of the variables of interest in direction although not significant. The instruments in model 15 seem to fit best in comparison to the models 13 and 14. The complementarity test shows no complementarity at conventional significance levels. This implies that the CSR variable Sustainability External Audit is a poor signal for environmental innovation in our sample.

\section{Discussion and concluding remarks}

The signalling literature suggests that signals serve as information on unobservable attributes (Spence 2002) to overcome information asymmetries. We apply the signalling theory to the environmental engagement of a firm. As such, we use firm's environmental R\&D activities, which are hard to observe for stakeholders. Therefore, a signal to communicate the firm's environmental activities as a whole is needed to differentiate from competitors and gain an advantage. CSR, which has become more and more important in the last years, can verify a firm's pro-social and pro-environmental engagement and serve as a signal. This is a signal in the sense of Wernerfelt's (1988) reputational economies of scale, which creates reputation not only for one product but for the firm as a whole. As such, CSR is a source of capabilities in the resource-based view of the firm: CSR creates reputation and in turn leads to higher financial performance. Thereby, we analyse if CSR as a signal complements the environmental R\&D activity of a firm and whether a joint strategy leads to higher financial performance.

Using data about global companies from the ASSET4 database, we examine if environmental R\&D and the reporting according to GRI guidelines are complementary, and consequently we research, if the joint strategy leads to better financial performance. Our different analyses rather support the hypothesis that a joint strategy of environmental R\&D and CSR reporting according to GRI leads to higher financial performance, although the effects are rather small. In other words, environmental innovators can verify their activity by GRI reporting and attract clients. How this works with specific clients such as consumers or investors should be addressed in further research.

However, our results do not allow a conclusion for CSR in general, which our additional analyses with a different CSR variable reveal. We cannot conclude that CSR per se is beneficial for environmental innovators. As already Orlitzky and Benjamin (2001) and Margolis et al. (2007) pointed out, the effect of CSR on the financial performance of a firm depends on the measurement of CSR. Our results support this viewpoint and reveal that not every kind of CSR is suitable to transport unobservable signals of firms' environmental R\&D engagement when applying signalling theory. Furthermore, the descriptive statistics might give additional explanation that the relation of environmental R\&D and CSR depends on the location of the firm and the industry. On the one hand, this supports the resource-based view of the firm that creating reputation which in turn leads to higher financial performance depends on the uniqueness of capabilities and their specific usage. Therefore, R\&D as well as CSR are not advantageous in general. On the other hand, the behavioural view comes into play suggesting that personal values are needed for a social strategy of the firm especially 
when we interpret our results against the background of the descriptive statistics, which say that in Europe and Asia more firms do both strategies together. Further research would be needed to analyse if such values are more expected or more accepted by firm's stakeholders in these countries than in other countries.

Further limits of our analysis accrue from data limitations. In particular, the different firm strategies might be object to endogeneity as they might contribute to the same personal management values. The instrumentation via the lagged variables and the moving averages is limited. The results need verification with additional data, which might be possible in the future as more and more data on GRI reporting will be available. Moreover, as the ASSET4 database mainly provides dichotomous variables, which might not change much over time, further research with more detailed data would give better insight. Another drawback is the composition of the sample with a huge number of firms in the service sector, which might report their CSR activity, but are not engaged in innovation.

Nevertheless, our study provides first results on complementarity of environmental R\&D and CSR related to the signalling theory. As such, it tries to overcome the drawback of previous cross-sectional analysis not accounting for unobservable factors by using panel data. We can verify that the signalling effect of CSR strongly depends on the type of CSR.

\section{Managerial implications}

Furthermore, our study has implication for the practice. The results reveal that managers should not engage CSR activities just for the sake of signalling that they are good. As the analyses show, not each reporting of CSR works equally well. Managers should first ensure if additional information on their pro-environmental (or also pro-social) engagement is necessary and appreciated by their clients. If this is the case, a signal can only work if it could carry the unobservable attributes and overcome the information asymmetry as intended. As such, it should be a credible signal which the clients are familiar with and which they can easily observe and verify. Third party certification of an overall CSR report might serve as a comprehensive signal for a firm's pro-environmental and pro-social engagement.

However, as the analyses show the effect on financial performance, although significant, is rather small. Nevertheless, as the demand for firms' engagement in environmental and social concerns might further increase, a strategy how to signal such activities might also become more important. 


\section{References}

Aboody, D. and B. Lev (2000), Information asymmetry, R\&D, and insider gains, The Journal of Finance 55 (6), 2747-2766.

Aghion, P. , N. Bloom , R. Blundell , R. Griffith and P. Howitt (2005), Competition and innovation: An inverted-U relationship, The Quarterly Journal of Economics 102 (2), 701-728.

Akerlof, G.A. (1970), The market for "lemons": Quality uncertainty and the market mechanism, The Quarterly Journal of Economics 84 (3), 488-500.

Ambec, S. , M.A. Cohen , S. Elgie and P. Lanoie (2013), The Porter Hypothesis at 20: Can environmental regulation enhance innovation and competitiveness?, Review of Environmental Economics and Policy 7 (1), 2-22.

Anderson, T.W. and C. Hsiao (1981), Estimation of dynamic models with error components, Journal of the American Statistical Association 76 (375), 598-606.

Arellano, M. and S. Bond (1991), Some tests of specification for panel data: Monte Carlo evidence and an application to employment equations, The Review of Economic Studies 58 (2), 277-297.

Arora, A. and A. Gambardella (1990), Complementarity and external linkages: The strategies of the large firms in biotechnology, The Journal of Industrial Economics 38 (4), 361379.

Arora, S. and T.N. Cason (1995), An experiment in voluntary environmental regulation participation in EPAs 33/50 program, Journal of Environmental Economics and Management 28 (3), 271-286.

Arora, S. and S. Gangopadhyay (1995), Toward a theoretical model of voluntary overcompliance, Journal of Economic Behavior \& Organization 28 (3), 289-309.

Baron, D.P. (2001), Private politics, corporate social responsibility, and integrated strategy, Journal of Economics \& Management Strategy 10 (1), 7-45.

Baron, D.P. (2009), A positive theory of moral management, social pressure, and corporate social performance, Journal of Economics \& Mangement Strategy 18 (1), 7-43.

Baron, D.P. (2010), Morally motivated self-regulation, The American Economic Review 100 (4), 1299-1329.

Baron, D.P. and D. Diermeier (2007), Strategic activism and nonmarket strategy, Journal of Economics \& Management Strategy 16 (3), 599-634.

Bénabou, R. and J. Tirole (2010), Individual and corporate social responsibility, Economica 77 (305), 1-19.

Bhattacharya, S. (1979), Imperfect information, dividend policy and "the bird in the hand" fallacy, The Bell Journal of Economics 10 (1), 259-270. 
Blundell, R. and S. Bond (1998), Initial conditions and moment restrictions in dynamic panel data models, Journal of Econometrics 87 (1), 115-143.

Bowen, F. (2007), Corporate social strategy: Competing views from two theories of the firm, Journal of Business Ethics 75 (1), 97-113.

Branco, M.C. and L.L. Rodrigues (2006), Corporate social responsibility and resource-based perspectives, Journal of Business Ethics 69 (2), 111-132.

Brynjolfsson, E. and P. Milgrom (2013), Complementarity in organizations. Pp.11-54 in The Handbook of Organizational Economics, edited by Robert Gibbons and John Roberts. Princeton and Oxford.

Calveras, A. , J.-J. Ganuza and G. Llobet (2007), Regulation, corporate social responsibility and activism, Journal of Economics \& Management Strategy 16 (3), 719-740.

Cañón-de-Francia, J. and C. Garcés-Ayerbe (2009), ISO 14001 environmental certification: A sign valued by the market?, Environmental and Resource Economics 44 (2), 245-262.

Carroll, A.B. (2013), A three-dimensional conceptual model of corporate performance, The Academy of Management Review 4 (4), 497-505.

Cavaco, S. and P. Crifo (2014), CSR and financial performance: Complementarity between environmental, social and business behaviours, Applied Economics 46 (27), 3323-3338.

Chauvin, K.W. and M. Hirschey (1994), Goodwill, profitability, and the market value of the firm, Journal of Accounting and Public Policy 13 (2), 159-180.

Cochran, P.L. and R.A. Wood (1984), Corporate social responsibility and financial performance, The Academy of Management Journal 27 (1), 42-56.

Cyert, R.M. and J.G. March (1963), A behavioural theory of the firm, Englewood Cliffs, NJ.

Dasgupta, S. , H. Hettige and D. Wheeler (2000), What improves environmental compliance? Evidence from Mexican industry, Journal of Environmental Economics and Management 39 (1), 39-66.

Donaldson, T. and L.E. Preston (1995), The stakeholder theory of the corporation: Concepts, evidence, and implications, Academy of Management Review 20 (1), 65-91.

Dowell, G. , S.L. Hart and B. Yeung (2000), Do corporate global environmental standards create or destroy market value?, Management Science 46 (8), 1059-1074.

Elhauge, E. (2005), Corporate managers' operational discretion to sacrifice corporate profits in the public interest, New York University Law Review 80 (3), 733-869.

Elsayed, K. and D. Paton (2005), The impact of environmental performance on firm performance: Static and dynamic panel data evidence, Structural Change and Economic Dynamics 16 (3), 395-412. 
Feddersen, T.J. and T.W. Gilligan (2001), Saints and markets: Activists and the supply of credence goods, Journal of Economics \& Management Strategy 10 (1), 149-171.

Fombrun, C.J. (1996), Reputation: realizing value from the corporate image, Boston.

Fombrun, C.J. and M. Shanley (1990), What's in a name? Reputation building and corporate strategy, Academy of Management Journal 33 (2), 233-258.

Freeman, R. (2010), Strategic management: A stakeholder approach, Digital pr. Cambridge.

Friedman, M. (1970), The social responsibility of business is to increase its profits, The New York Times Magazine.

Gorodnichenko, Y. , J. Svejnar and K. Terrell (2010), Globalization and innovation in emerging markets, American Economic Journal: Macroeconomics 2 (2), 194-226.

Graff Zivin, J. and A. Small (2005), A Modigliani-Miller theory of altruistic corporate social responsibility, Topics in Economic Analysis \& Policy 5 (1), Article 10.

Griffin, J.J. and J.F. Mahon (1997), The corporate social performance and corporate financial performance debate: twenty-five years of incomparable research, Business \& Society 36 (1), 5-31.

Griliches, Z. (1979), Issues in assessing the contribution of research and development to productivity growth, The Bell Journal of Economics 10 (1), 92-116.

Griliches, Z. (1981), Market value, R\&D, and patents, Economics Letters 7 (2), 183-187.

Griliches, Z. (1990), Patent statistics as economic indicators: A survey, Journal of Economic Literature 28 (4), 1661-1707.

Griliches, Z. , A. Pakes and B.H. Hall (1986), The value of patents as indicators of inventive activity, NBER Working Paper Series, Cambridge, MA.

Harrington, D.R. , M. Khanna and G. Deltas (2008), Striving to be green: The adoption of total quality environmental management, Applied Economics 40 (23), 2995-3007.

Hart, S.L. (1995), A natural-resource-based view of the firm, The Academy of Management Review 20 (4), 986-1014.

Hart, S.L. and G. Ahuja (1996), Does it pay to be green? An empierical examination of the relationship between emission reduction and firm performance, Business Strategy and the Environment 5 (1), 30-37.

Heras-Saizarbitoria, I. and O. Boiral (2013), ISO 9001 and ISO 14001: Towards a research agenda on management system standards, International Journal of Management Reviews 15 (1), 47-65.

Heras-Saizarbitoria, I. , J.F. Molina-Azorín and G.P.M. Dick (2011), ISO 14001 certification and financial performance: Selection-effect versus treatment-effect, Journal of Cleaner Production 19 (1), 1-12. 
Hopenhayn, H.A. (1992), Entry, exit, and firm dynamics in long run equilibrium, Econometrica 60 (5), 1127-1150.

Hull, C.E. and S. Rothenberg (2008), Firm performance: the interactions of corporate social performance with innovation and industry differentiation, Strategic Management Journal 29 (7), 781-789.

Husted, B.W. (2005), Risk management, real options, corporate social responsibility, Journal of Business Ethics 60 (2), 175-183.

Husted, B.W. and D.B. Allen (2000), Is it ethical to use ethics as strategy?, Journal of Business Ethics 27 (1-2), 21-31.

Husted, B.W. and D.B. Allen (2007a), Corporate social strategy in multinational enterprises: Antecedents and value creation, Journal of Business Ethics 74 (4), 345-361.

Husted, B.W. and D.B. Allen (2007b), Strategic corporate social responsibility and value creation among large firms. Lessons from the Spanish experience, Long Range Planning 40 (6), 594-610.

Jaffe, A.B. , S.R. Peterson , P.R. Portney and R.N. Stavins (1995), Environmental regulation and the competitiveness of U.S. manufacturing: What does the evidence tell us?, Journal of Economic Literature 33 (1), 132-163.

King, A.A. and M.J. Lenox (2000), Industry self-regulation without sanctions: The chemical industry's responsible care program, Academy of Management Journal 43 (4), 698-716.

King, A.A. and M.J. Lenox (2001), Does it really pay to be green?, Journal of Industrial Ecology 5 (1), 105-116.

Kitzmueller, M. and J. Shimshack (2012), Economic perspectives on corporate social responsibility, Journal of Economic Literature 50 (1), 51-84.

Klassen, R.D. and C.P. McLaughlin (1996), The impact of environmental management on firm performance, Management Science 42 (8), 1199-1214.

Kleinknecht, A. , K. van Montfort and E. Brouwer (2002), The non-trivial choice between innovation indicators, Economics of Innovation and New Technology 11 (2), 109-121.

Konar, S. and M.A. Cohen (2001), Does the market value environmental performance?, Review of Economics and Statistics 83 (2), 281-289.

Kotchen, M.J. (2006), Green markets and private provision of public goods, Journal of Political Economy 114 (4), 816-834.

Levin, R.C. et al. (1987), Appropriating the returns from industrial research and development, Brookings Papers on Economic Activity Special Is (3), 783-831.

Lioui, A. and Z. Sharma (2012), Environmental corporate social responsibility and financial performance: disentangling direct and indirect effects, Ecological Economics 78, 100111. 
Lyon, T.P. and J.W. Maxwell (2008), Corporate social responsibility and the environment: A theoretical perspective, Review of Environmental Economics and Policy 2 (2), 240-260.

Margolis, J.D. , H.A. Elfenbein and J. Walsh (2007), Does it pay to be good? A meta-analysis and redirection of research on the relationship between corporate social and financial performance, Ann Arbor 1001, 48109-1234.

Maxwell, J.W. , T.P. Lyon and S.C. Hackett (2000), Self-regulation and social welfare: The political economy of corporate environmentalism, Journal of Law \& Economics 43 (2), 583-617.

McGuire, J.B. , A. Sundgren and T. Schneeweis (1988), Corporate social responsibility and firm financial performance, Academy of Management Journal 31 (4), 854-872.

McWilliams, A. and D. Siegel (2000), Corporate social responsibility and financial performance: Correlation or misspecification?, Strategic Management Journal 21 (5), 603-609.

Melnyk, S.A. , R.P. Sroufe and R. Calantone (2003), Assessing the impact of environmental management systems on corporate and environmental performance, Journal of Operations Management 21 (3), 329-351.

Milgrom, P. and J. Roberts (1986), Price and advertising signals of product quality, Journal of Political Economy 94 (4), 796-821.

Milgrom, P. and J. Roberts (1990), The economics of modern manufacturing: Technology, strategy, and organization, The American Economic Review 80 (3), 511-528.

Milgrom, P. and J. Roberts (1995), Complementarities and fit strategy, structure, and organizational change in manufacturing, Journal of Accounting and Economics 19 (2-3), $179-208$.

Miravete, E.J. and J.C. Pernías (2010), Testing for complementarity when strategies are dichotomous, Economics Letters 106 (1), 28-31.

Nakamura, M. , T. Takahashi and I. Vertinsky (2001), Why Japanese firms choose to certify: A study of managerial responses to environmental issues, Journal of Environmental Economics and Management 42 (1), 23-52.

Nickell, S.J. (1996), Competition and corporate performance, Journal of Political Economy 104 (4), 724-746.

Nishitani, K. (2009), An empirical study of the initial adoption of ISO 14001 in Japanese manufacturing firms, Ecological Economics 68 (3), 669-679.

Nishitani, K. (2010), Demand for ISO 14001 adoption in the global supply chain: An empirical analysis focusing on environmentally conscious markets, Resource and Energy Economics 32 (3), 395-407.

OECD and European Commission (2005), Oslo Manual: guidelines for collecting and interpreting innovation data, 3rd ed. 
Orlitzky, M. (2005), Social responsibility and financial performance: Trade-off or virtuous circle?, University of Auckland Business Review 7 (1), 37-43.

Orlitzky, M. and J.D. Benjamin (2001), Corporate social performance and firm risk: A metaanalytic review, Business \& Society 40 (4), 369-396.

Orlitzky, M. , F.L. Schmidt and S.L. Rynes (2003), Corporate social and financial performance: A meta-analysis, Organization Studies 24 (3), 403-441.

Pava, M.L. and J. Krausz (1996), The association between corporate social-responsibility and financial performance: The paradox of social cost, Journal of Business Ethics 15 (3), 321-357.

Penrose, E. (1959), The theory of the growth of the firm, Oxford.

Poddi, L. and S. Vergalli (2009), Does corporate social responsibility affect the performance of firms?, Fondazione Enri Enrico Mattei 52 (09), Mailand.

Porter, M.E. and C. van der Linde (1995), Toward a new conception of the environmentcompetitiveness relationship, The Journal of Economic Perspectives 9 (4), 97-118.

Potoski, M. and A. Prakash (2005), Green clubs and voluntary governance: ISO 14001 and firms’ regulatory compliance, American Journal of Political Science 49 (2), 235-248.

Preston, L.E. and D.P. O’Bannon (1997), The corporate social-financial performance relationship: A typology and analysis, Business \& Society 36 (4), 419-429.

Reinhardt, F.L. , R.N. Stavins and R.H.K. Vietor (2008), Corporate social responsibility through an economic lens, Review of Environmental Economics and Policy 2 (2), 219239.

Rennings, K. , A. Ziegler , K. Ankele and E. Hoffmann (2006), The influence of different characteristics of the EU environmental management and auditing scheme on technical environmental innovations and economic performance, Ecological Economics 57 (1), 45-59.

Rexhäuser, S. and C. Rammer (2014), Environmental innovations and firm profitability: Unmasking the porter hypothesis, Environmental and Resource Economics 57 (1), 145167.

Riley, J.G. (2001), Silver signals : twenty-five years of screening and signaling, Journal of Economic Literature 39 (2), 432-478.

Ross, S.A. (1977), The determination of financial structure: The incentive-signalling approach, The Bell Journal of Economics 8 (1), 23-40.

Russo, M. V. and P.A. Fouts (1997), A resource-based perspective on corporate environmental performance and profitability, Academy of Management Journal 40 (3), 534-559. 
Smith, K. (2005), Measuring innovation. Pp.148-177 in The Oxford Handbook of Innovation, edited by Jan Fagerberg, David C. Mowery, and Richard R. Nelson. New York.

Smith, W.K. and M.W. Lewis (2011), Toward a theory of paradox: A dynamic equilibrium model of organizing, Academy of Management Review 36 (2), 381-403.

Spence, M. (1973), Job market signaling, The Quarterly Journal of Economics 87 (3), 355374.

Spence, M. (2002), Signaling in retrospect and the informational structure of markets, The American Economic Review 92 (3), 434-459.

Staiger, D. and J.F. Stock (1997), Instrumental variables regression with weak instruments, Econometrica 65 (3), 557-586.

Telle, K. (2006), “It pays to be green” - A premature conclusion?, Environmental and Resource Economics 35 (3), 195-220.

Terlaak, A. (2007), Satisficing signaling: corporate social strategy and certified management standards, Academy of Management Proceedings August (1), 1-6.

Terlaak, A. and A.A. King (2006), The effect of certification with the ISO 9000 quality management standard: A signaling approach, Journal of Economic Behavior \& Organization 60 (4), 579-602.

The Economist (2008), Just good business. Special report: Corporate social responsibility.

Toms, J.S. (2002), Firm resources, quality signals and the determinants of corporate environmental reputation: some UK evidence, The British Accounting Review 34 (3), 257-282.

Waddock, S.A. and S.B. Graves (1997), The corporate social performance- financial performance link, Strategic Management Journal 18 (4), 303-319.

Wagner, M. (2007), On the relationship between environmental management, environmental innovation and patenting: Evidence from German manufacturing firms, Research Policy 36 (10), 1587-1602.

Watts, R.L. and J.L. Zimmermann (2002), Positive accounting theory, 2nd ed. Prentice-Hall, New Jersey.

Wernerfelt, B. (1984), A resource-based view of the firm, Strategic Management Journal 5 (2), 171-180.

Wernerfelt, B. (1988), Umbrella branding as a signal of new product quality: An example of signalling by posting a bond, The RAND Journal of Economics 19 (3), 458-466. 


\section{Appendix}

Table 7: Overview Industry Sectors (6,737 observations)

\begin{tabular}{lrr}
\hline Industry Sectors SIC & $\begin{array}{r}\text { No. of } \\
\text { observations }\end{array}$ & Percent \\
\hline Mining & 364 & $5.40 \%$ \\
Construction & 237 & $3.52 \%$ \\
Manufacture Food & 297 & $4.41 \%$ \\
Manufacture Wood, Paper, Print & 279 & $4.14 \%$ \\
Manufacture Chemicals & 525 & $7.79 \%$ \\
Manufacture Metal, Machinery, Transport Eq. & 698 & $10.36 \%$ \\
Manufacture Computers, Electronic Eq. & 480 & $7.12 \%$ \\
Manufacture Others & 599 & $8.89 \%$ \\
Transport, Communication, Electric & 843 & $12.51 \%$ \\
Wholesale and Retail Trade & 583 & $8.65 \%$ \\
Finance, Insurance, Real Estate & 1,281 & $19.01 \%$ \\
Services & 551 & $8.18 \%$ \\
\hline Total & 6,737 & $100.00 \%$ \\
\hline
\end{tabular}

Table 8: Overview environmental R\&D and CSR variables

\begin{tabular}{rrrrrr}
\hline Year & Overall & \multicolumn{2}{c}{ Environmental R\&D } & \multicolumn{2}{c}{ CSR } \\
\hline & $\begin{array}{r}\text { No. of } \\
\text { obs. }\end{array}$ & $\begin{array}{r}\text { No. of observed } \\
\text { firms with R\&D }\end{array}$ & $\begin{array}{r}\text { Share of observed } \\
\text { firms with R\&D }\end{array}$ & $\begin{array}{r}\text { No. of observed } \\
\text { firms with CSR }\end{array}$ & $\begin{array}{r}\text { Share of observed } \\
\text { firms with CSR }\end{array}$ \\
\hline $\mathbf{2 0 0 5}$ & 781 & 51 & $6.53 \%$ & 66 & $8.45 \%$ \\
$\mathbf{2 0 0 6}$ & 1,377 & 82 & $5.95 \%$ & 119 & $8.64 \%$ \\
$\mathbf{2 0 0 7}$ & 1,751 & 234 & $13.36 \%$ & 394 & $22.50 \%$ \\
$\mathbf{2 0 0 8}$ & 1,724 & 372 & $21.58 \%$ & 547 & $31.73 \%$ \\
$\mathbf{2 0 0 9}$ & 1,104 & 300 & $27.17 \%$ & 375 & $33.97 \%$ \\
\hline Total & 6,737 & 1,039 & $15.42 \%$ & 1,501 & $22.28 \%$ \\
\hline
\end{tabular}




\section{Figure 1: Development of the topic CSR in research}

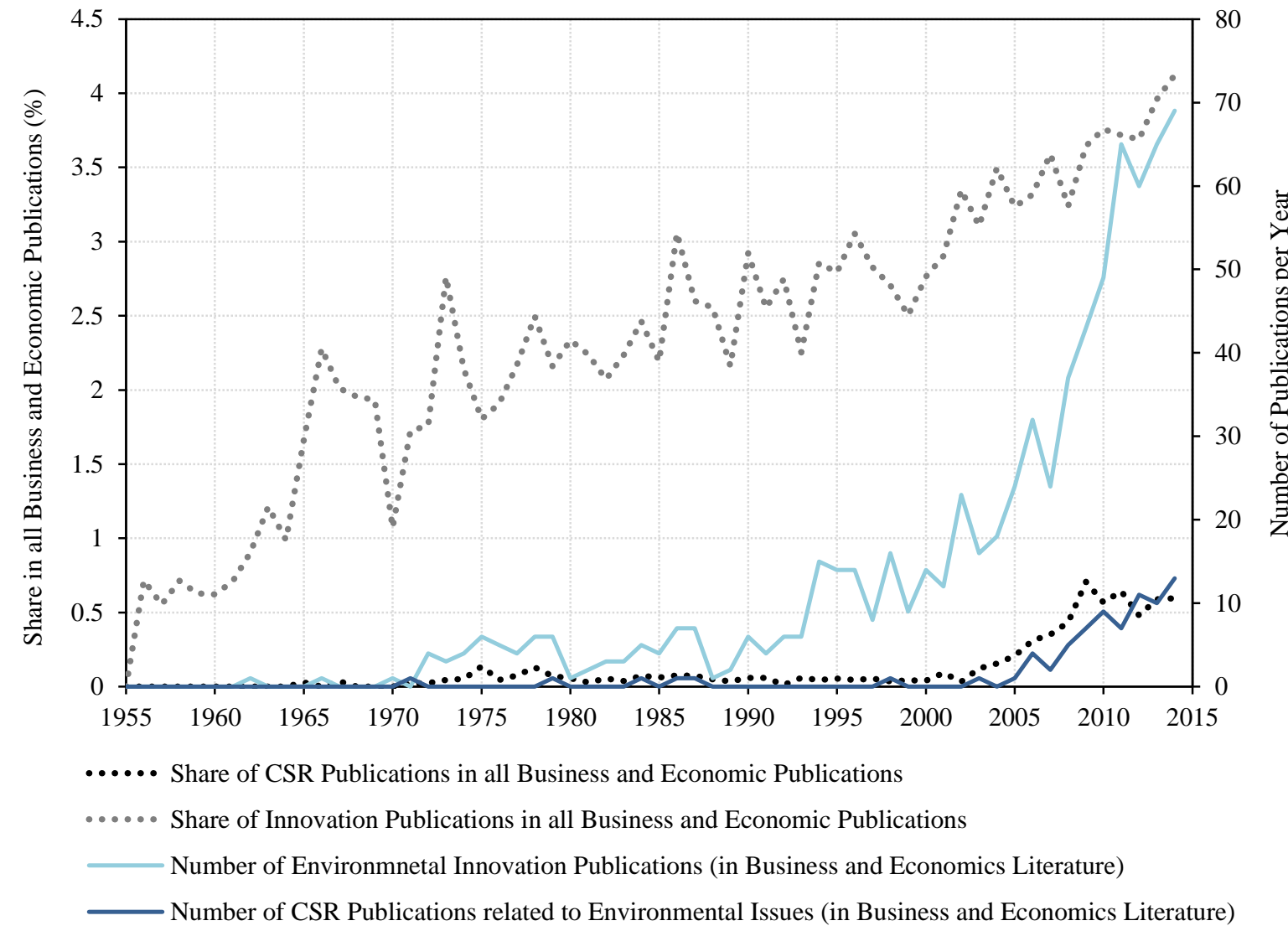

Note: Since 1955 and 2014, 532,981 publications (journal articles) in the business and economic literature are reported in the Web of Science database, where the year 2014 contributes to this sum with 24,351 publications. The overall number of 1,194 journal articles in the subfield of Corporate Social Responsibility has been identified on the base of the appearance of at least one of the following keywords in the articles' title: "Corporate Social Responsi*”, or CSR, or "Corporate Social Performance”, or "CSP", or "Corporate Responsi*", where the wildcard * represents any further letters. The black dotted line refers to the share of these CSR publications in all economic and business publications in percent (left ordinate axis).

In a similar fashion, the 15,347 articles in the business and economics literature dealing with innovation and technical change have been selected in case at least one of the following non-key sensitive key words appeared in the title: Inventi*, or Innovati*, or "Techn* Change", or "Research and Development", or R\&D, or Technology. CSR publications related to the area of environmental issues have been identified based on the appearance of at least one aforementioned CSR key word in the title as well as one of the following key words: Environment*, or “Eco-*”, or "Resource-Saving”, or “Energy*”, or Carbon, or "Climate Change”, or Pollution, or "Pollution Control”, or "Pollution Abatement”, or "Sustainab*”, or Clean, or Wind, or Solar, or Photovoltaic, or Biomass.

However, the selection of the key words is highly subjective so the results provided in Figure 1 do not claim completeness. 
Figure 2: Unbalanced panel data sample (6737 observations)

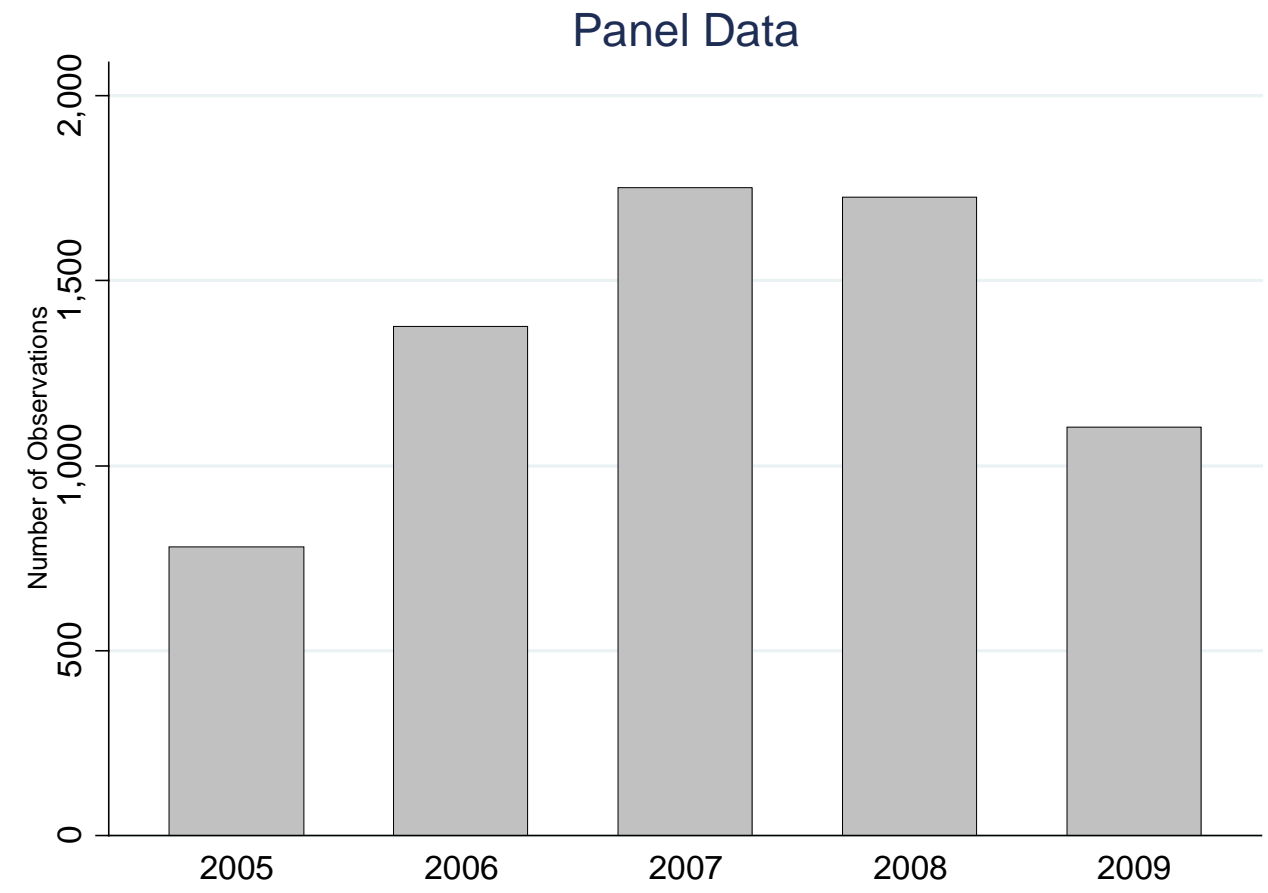

Figure 3: Sample and environmental R\&D

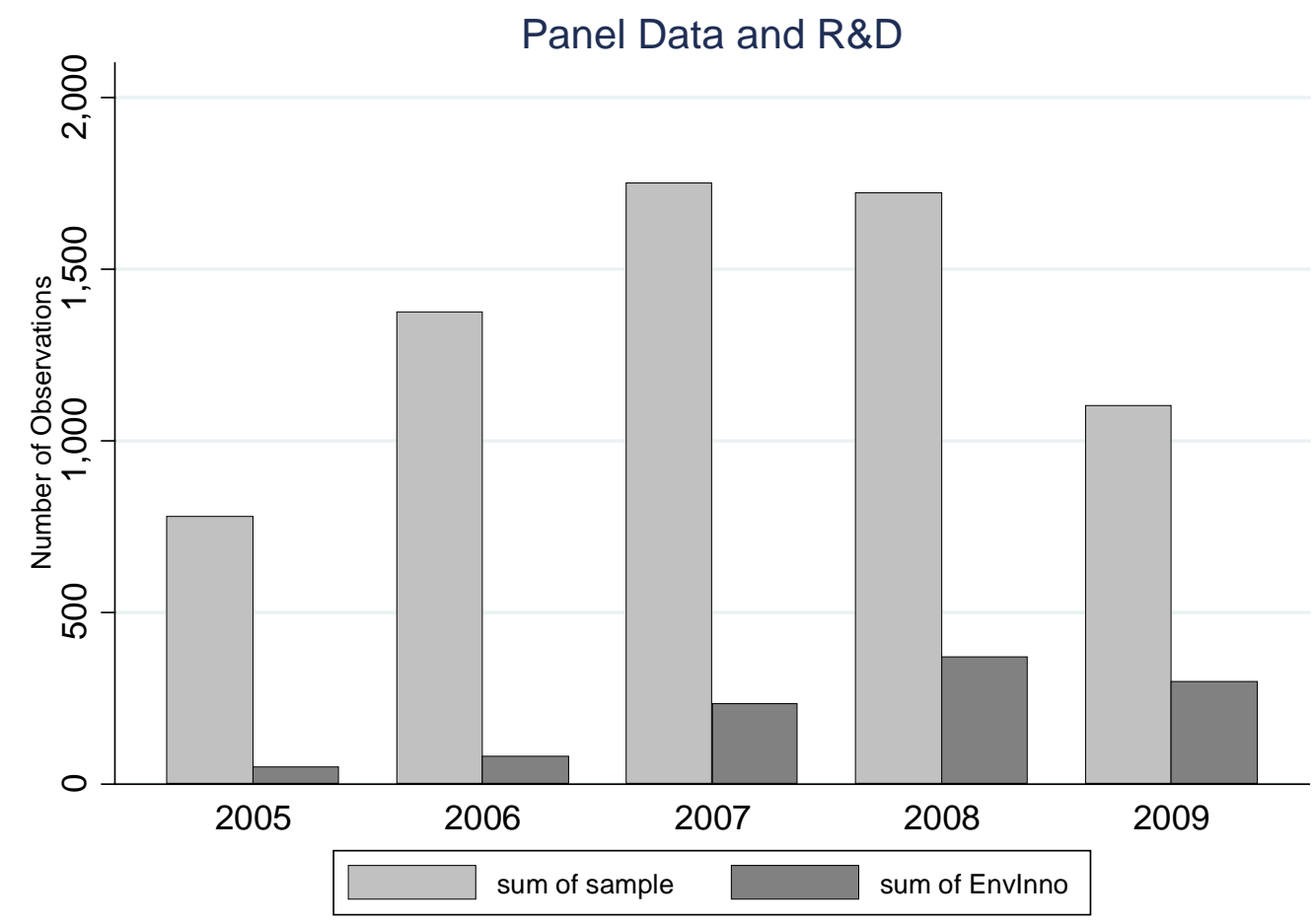


Figure 4: Sample and CSR

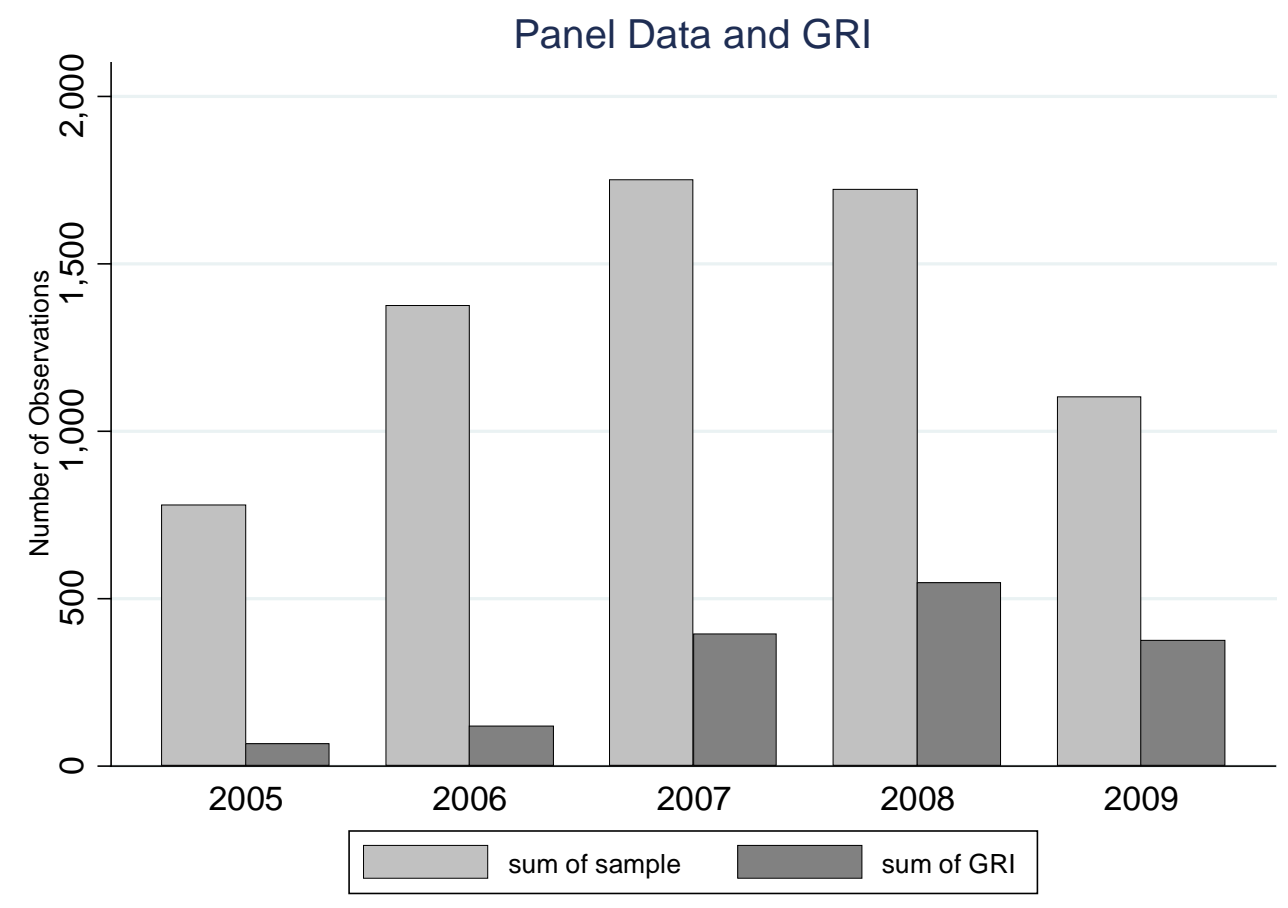

Figure 5: Overview panel data and innovation and CSR categories

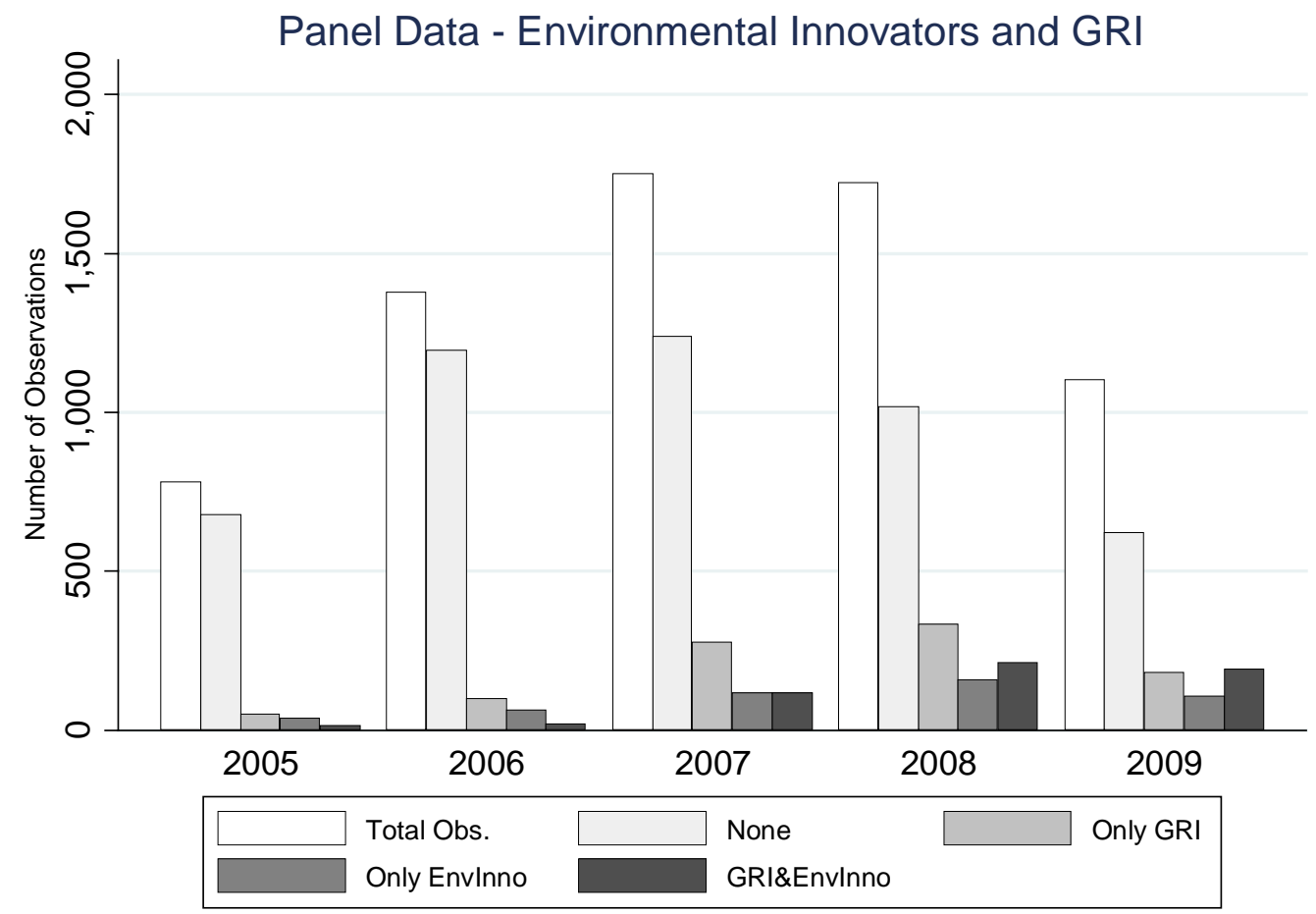


Figure 6: Overview panel data and innovation and CSR categories by continents

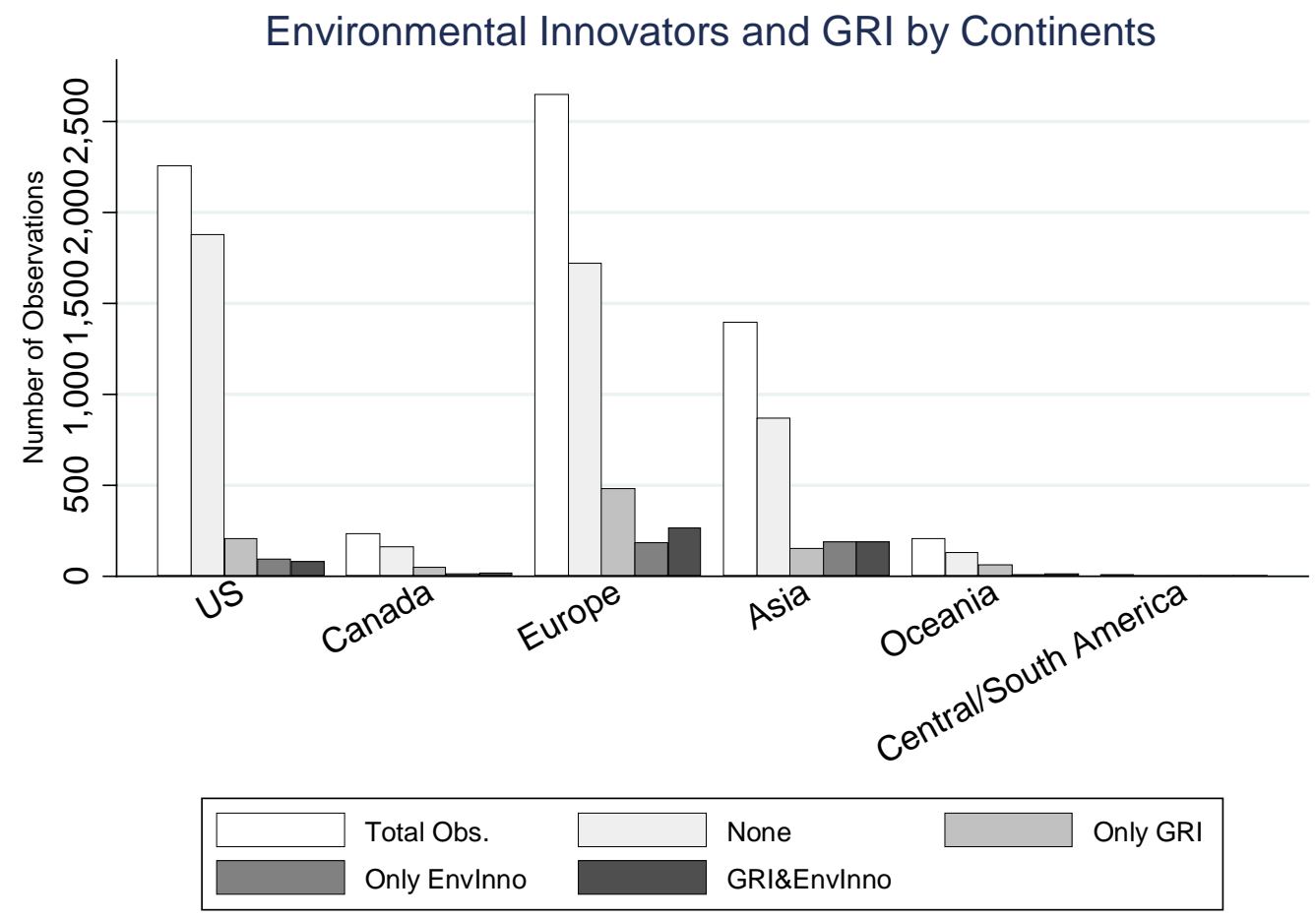

Figure 7: Overview panel data and innovation and CSR categories by industry

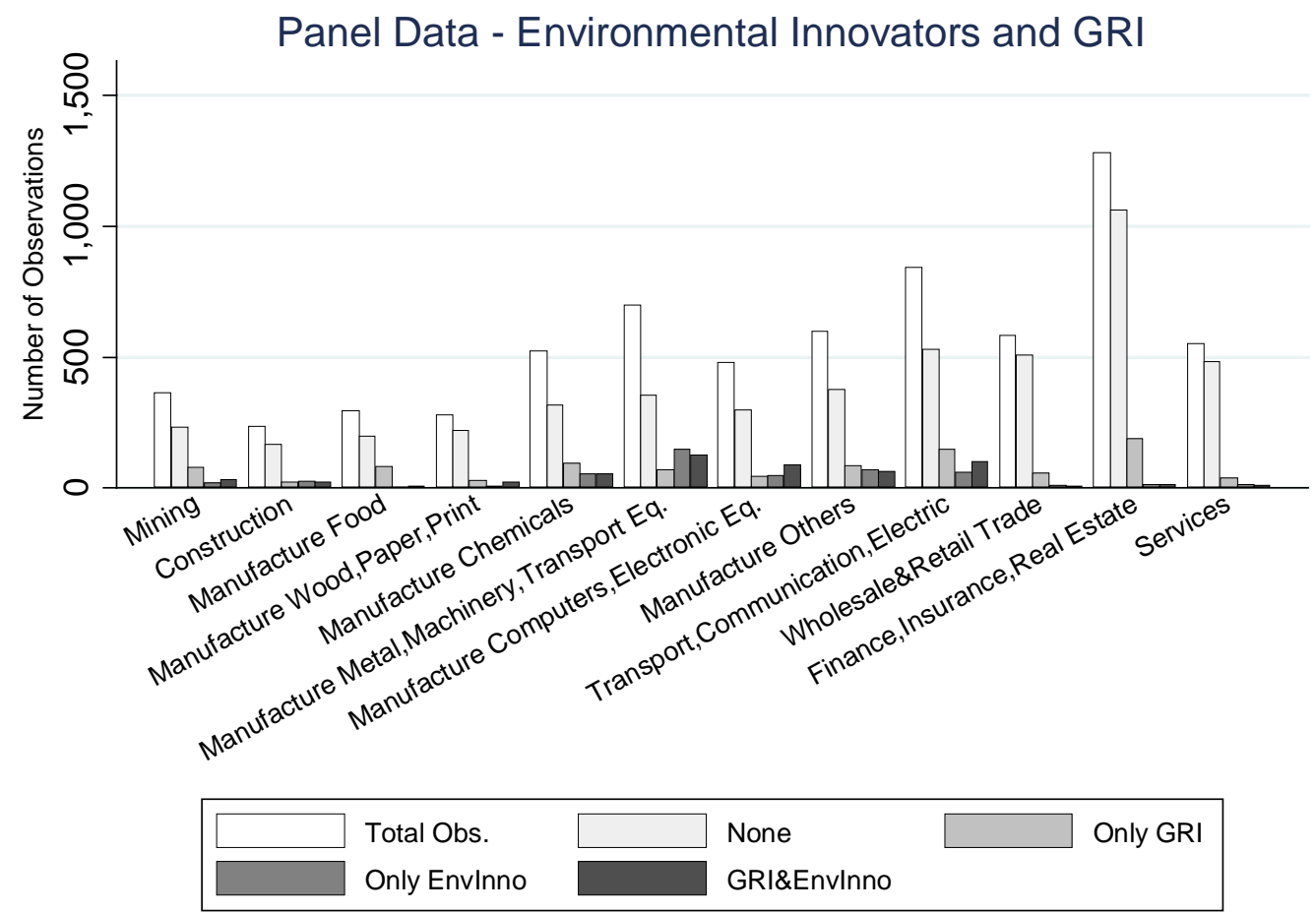




\section{Anderson-Hsiao Estimator}

Table 9 below provides the results for the basic dynamic model setup where the endogeneity of the lagged dependent variables has been accounted for but not the endogeneity of the key variables of interest.

Table 9: Estimation Results Anderson-Hsiao Estimator

\begin{tabular}{|c|c|c|}
\hline Dependent variable: & $\begin{array}{c}\text { (App. 1) } \\
\text { AH robust } \\
\Delta \ln \left(\mathrm{P} / \mathrm{S}_{\mathrm{it}}\right) \\
\end{array}$ & $\begin{array}{c}\text { (App. 2) } \\
\text { First Stage } \\
\Delta \ln \left(\mathbf{P} / \mathrm{S}_{\mathrm{it}-1}\right) \\
\end{array}$ \\
\hline$\Delta \ln (P / S)_{i t-1}$ & $\begin{array}{c}-2.754^{* *} \\
(1.093)\end{array}$ & \\
\hline$\Delta \ln (P / S)_{i t-2}$ & & $\begin{array}{l}0.0478 * * \\
(0.0198)\end{array}$ \\
\hline$\Delta$ Beta $_{i t}$ & $\begin{array}{c}-0.397 * * * \\
(0.0756)\end{array}$ & $\begin{array}{c}-0.0268 \\
(0.0198)\end{array}$ \\
\hline$\Delta G D P-G r o w t h h_{i t}$ & $\begin{array}{c}30.02 * * * \\
(8.807)\end{array}$ & $\begin{array}{l}8.003^{* * *} \\
(0.292)\end{array}$ \\
\hline$\Delta \ln (\text { Sales })_{i t}$ & $\begin{array}{c}0.349 \\
(0.413)\end{array}$ & $\begin{array}{l}0.357 * * * \\
(0.0338)\end{array}$ \\
\hline$\Delta \ln (\text { Labour/Sales })_{i t}$ & $\begin{array}{c}0.0353 \\
(0.0828)\end{array}$ & $\begin{array}{c}0.0357 \\
(0.0282)\end{array}$ \\
\hline$\Delta \ln (\text { Patents })_{i t}$ & $\begin{array}{c}-0.00836 \\
(0.0107)\end{array}$ & $\begin{array}{l}-0.00137 \\
(0.00383)\end{array}$ \\
\hline$\Delta \ln (A g e)_{i t}$ & $\begin{array}{l}-0.0645 \\
(0.308)\end{array}$ & $\begin{array}{l}-0.0667 \\
(0.114)\end{array}$ \\
\hline$\Delta$ EnvInno $_{t}$ & $\begin{array}{c}0.0558 \\
(0.0719)\end{array}$ & $\begin{array}{l}0.0456 * * \\
(0.0184)\end{array}$ \\
\hline$\Delta C S R_{i t}$ & $\begin{array}{c}0.106 \\
(0.0724)\end{array}$ & $\begin{array}{c}0.0570 * * * \\
(0.0140)\end{array}$ \\
\hline$\Delta B O T H_{i t}$ & $\begin{array}{c}0.207^{* *} \\
(0.104)\end{array}$ & $\begin{array}{c}0.0809 * * * \\
(0.0221)\end{array}$ \\
\hline Constant & $\begin{array}{c}0.0412 \\
(0.0277)\end{array}$ & $\begin{array}{c}0.0123 \\
(0.00786)\end{array}$ \\
\hline Observations & 5,633 & 5,633 \\
\hline $\begin{array}{l}\text { R-squared } \\
\text { rho }\end{array}$ & . & $\begin{array}{c}0.219 \\
. \\
\end{array}$ \\
\hline $\begin{array}{l}\text { Note: Robust standarc } \\
* * * p<0.01, * * p<0.0\end{array}$ & theses. & \\
\hline
\end{tabular}

The most obvious insight from this table is that the coefficient estimate of the lagged dependent variable is far away from plausible values and far away from the very basic OLS estimates provided in Table 3. The likely reason is a considerable instrumental variable bias due to a weak instrument problem. Recall that the results from Table 9 rely on a mode setup where all variables enter the model in differences. Although the correlation of the price-tosales ratio in period $t$ and $t-1$ is relatively high (0.883), the correlation of the first differences and lagged first differences is very small (-0.2354) making it a bad instrument. Taking furthermore the first stage regressions into account supports this view. The coefficient estimate of the excluded instrument in the structural equation is relatively low let alone the fact that its level of significance is rather small supporting the concern of a weak instrument problem. In particular, the F-statistic of the excluded instrument in the first stage regression 
$(\mathrm{F}=5.81)$ is far away from areas seen as to support non-weakness of instruments. Staiger and Stock (1997) propose a rule of thumb of a value of 10 for the first stage F-statistic of a single excluded instrument to provide evidence for non-weakness. The central insight from this simple experiment is straightforward. Even in this basic setup which only addresses the endogeneity of one variable, namely the lagged dependent variable, the Anderson-Hsiao estimator performs rather poorly given our data as lagged differences of the price-to-sales ratio, which is only loosely correlated little with current values. Therefore, further lags as instrument might help mitigate this problem as in the Arellano-Bond GMM case. In this sense, the Arellano-Bond estimator seems to be a better choice allowing more consistent estimates, at least in part. 